\title{
A Feasibility Study For Establishing A Sports Stadium To Stimulate Sport Tourism In Luxor Governorate
}

\author{
Prof. Dr. Rehab Ali Amin Osman
}

\section{Research problem and its importance:}

Tourism has become one of the most important major industries in the world as it works to attract capital and hard currencies, and helps in the employment of a large number of manpower and eliminate unemployment.

Jasim Mohamed Abdel-Hakim (2003) indicates that sport tourism has spread in countries that have natural factors, and a new global trend has begun to link between tourism and sports to achieve the service of each other, so tourism of the modern era has become sports tourism. (13: 18)

Heather J. Gibson (2007) explains the importance of sport tourism as being one of the most important modern tourist attractions that achieve diversity and change in the sources of tourist attraction. The practice of sport activities contributes to the revitalization of the tourism movement, whether internal or external, which leads to an increase in the national economy and thus an increase in the rate of income. $(19: 32$

According to the statistics of the Central Agency for Public Mobilization and Information Statistics (2019), it confirmed that the tourism revenue in (2017) was (7.5) billion dollars, and in (2018) it was (6.1) billion dollars, and the relative distribution of tourists according to the places of visit According to the statistics of (2018) (22.6\%) for Luxor, (18.7\%) for the Pyramids of Giza, (14.9\%) for Aswan, (11.6\%) for the Egyptian Museum, (6.9\%) for South Sinai. (9: 11)

The researcher noted through the analysis of these statistics that tourism revenues decreased to about one billion and seven hundred thousand dollars in (2018) from the investigator (2017), and that one of the most attractive areas for tourists is the governorate of Luxor, as the governorate suffers from the lack or availability of sports facilities suitable for holding various championships and sporting events. (39)

By examining the classification of the Ministry of Youth and Sports for Sports Clubs in the Arab Republic of Egypt (Attachment 3), the researcher found that Luxor Governorate contains three major clubs, namely Al Salam Sports Club, with an area of (21216), Luxor Sports Club with an area of (1300), and Al Madinah Al Monawrah Club with an area of (23100).

From this standpoint, the researcher carried out an exploratory study with the aim of identifying the extent of the ability to organize tournaments and sporting events on these stadiums on a number of (15) individuals from the sporting activity management and the managers of these clubs mentioned above. From the data results it's ound that there's no suitable location for hosting championships and sporting events, in addition to the absence of an integrated sports stadium for hosting sporting events.

The researcher also conducted a survey study on a number of tourism and sports officials with a total of (10) individuals to identify the extent of their acceptance to establish a sports stadium and its effect on activating sports tourism in Luxor Governorate. From it's results it was found a total agreement of $100 \%$ to establish an athletic stadium and positive effect to the revitalization of sport tourism in the governorate. 
The researcher also reviewed the results of previous studies that dealt with sports tourism, including the study of Sally Saeed Abdo (2016) (35), the study of Hamad Ynu Omar (2006) (15), and the study of Ahmed Nabil Al Sheikh (2004) (4) and from it's important results that confirmed the importance of sport tourism in the Arab Republic of Egypt and its necessity to develop tourist attractions in it, and that sporting facilities in many places are not suitable for serving sport tourism.

From the foregoing, the researcher believes that studying sports tourism in Luxor is a necessary requirement from the national side of the country in general and the scientific side in particular.

Youssef Attia Al-Thebaiti (2010) emphasized that it is difficult to determine the cost of establishing a sports facility even when compared to the other facilities in addition to the cost of the facility itself there are other costs which require feasibility studies that analyze all aspects related to the implementation of the project. (38: 111)

Ahmed Abdel Samie Allam (2008) and Abdelmutallab Abdel Hamid Mohamed (2000) agree that feasibility studies are divided into two main types, which are preliminary feasibility studies, which is an exploratory study, that is the sensor of the conditions and circumstances through which a decision can be taken to enter into detailed feasibility studies or not, and the second type is detailed feasibility studies that relate to the technical, financial, marketing, social and legal aspects. (2: 28) (1:42)

The researcher also reviewed the previous studies of Emama Samir Muhammad (2000) (10), Khalifa Talib Behbehani, Jawad Khalaf Hashem (2001) (22), Mona Abdul Aziz Issa (2008) (27), Sally Said Abdu (2016) (35), Hamad Yeno Omar (2006) (15), Ahmed Nabil Kamel Al-Sheikh (2004) (4), Nadia Lotfy Abdel-Fattah (2008) (28), Nadia Lotfy Abdel-Fattah Moawad (2012) (29), Basma Ibrahim Abdel Al-Basir (2015) (7), Salem Khalaf Fahd (2017) (34) Preuss \& Messing (2002) (30), Freyer W (2001) (12), Weaver \& Lawton (2009) (37), Kurtzman \& Zauhar (2005) (23), Bartoluc, Orrcen, Andrijasevic (2006) (6), Ruaridh Arrow (2008) (31). Among the most important results were the lack of adequate information services on sports competitions held in Egypt, that sporting events provide job opportunities, development of tourist transport services and increase the number of tourists and intra-host infrastructure of the country.

In light of the foregoing, the subject of the research that motivated the researcher towards carrying out this research and its title is clear:

"A feasibility study for establishing a sports stadium to stimulate sport tourism in Luxor Governorate"

Research aims Knowing the

- current status of the sports facilities in Luxor.

- The role of officials in stimulating sport tourism in Luxor.

- The importance of establishing a sports stadium and its effect on stimulating sport tourism and the target audience for its establishment

- The capabilities required to establish a sports stadium in Luxor Governorate.

- Reaching a feasibility study to establish a sports stadium to stimulate sports tourism in Luxor including (technical feasibility study - financial feasibility marketing feasibility - social feasibility legal feasibility). 


\section{Research questions:}

- What is the current state of the sports facilities in Luxor.

- What is the role of officials in stimulating sport tourism in Luxor.

- What is the importance of establishing a sports stadium and its effect on stimulating sport tourism and the target audience for its establishment.

- What are the capabilities required to establish a sports stadium in Luxor.

- What is the proposed scenario for the feasibility study to establish a sports stadium to stimulate sports tourism in Luxor.

\section{Research Procedures :}

\section{Research Methodology:}

The researcher used the descriptive survey method to suit the research nature.

\section{Research Sample:}

The basic sample of the research reached (168) individuals, including (officials and workers in the Ministry of Youth and Sports - officials and workers in the Ministry of Tourism - some academic professors in the colleges of physical education and colleges of tourism and hotels), and (26) individuals were identified for the exploratory study

Data collection tools: The researcher used two questionnaire forms where the first questionnaire is for the exploratory study, and the second one is for the feasibility study.

\section{First questionnaire (exploratory study):}

The researcher used the questionnaire to collect data to conduct the exploratory study.

\section{Scientific transactions for the survey questionnaire:}

A- Validate the content for the statements of the first questionnaire (exploratory study):

- The researcher relied on the validity of the questionnaire on the validity of the arbitrators and their number reached (11) arbitrators in order to know the extent of the suitability of the axes and statements and their clarity.

B- Validate the internal colleration coefficient of the statements of the initial questionnaire (exploratory study):

The correlation coefficient was calculated between the statements and the total sum of the axis to which it belongs after deleting the degree of the statement and is shown in Table (1) 
Table (1) coefficient of internal consistency (coefficient of correlation of the degree of the statement with the total sum of the axis to which it belongs) for the questionnaire expressions $(n=26)$

\begin{tabular}{|c|c|c|c|c|c|c|c|c|c|c|c|}
\hline \multirow[b]{2}{*}{ No. } & \multicolumn{2}{|c|}{ Coeff. } & \multirow[b]{2}{*}{ No. } & \multicolumn{2}{|c|}{ Coeff. } & \multirow[b]{2}{*}{ No. } & \multicolumn{2}{|c|}{ Coeff. } & \multirow{2}{*}{ No. } & \multicolumn{2}{|c|}{ Coeff. } \\
\hline & $\begin{array}{l}\text { With } \\
\text { axis }\end{array}$ & $\begin{array}{l}\text { With } \\
\text { total } \\
\text { score }\end{array}$ & & $\begin{array}{l}\text { With } \\
\text { axis }\end{array}$ & $\begin{array}{l}\text { With } \\
\text { total } \\
\text { score }\end{array}$ & & $\begin{array}{l}\text { With } \\
\text { axis }\end{array}$ & $\begin{array}{l}\text { With } \\
\text { total } \\
\text { score }\end{array}$ & & $\begin{array}{l}\text { With } \\
\text { axis }\end{array}$ & $\begin{array}{l}\text { With } \\
\text { total } \\
\text { score }\end{array}$ \\
\hline \multicolumn{2}{|c|}{ First axis } & & $6 / 1$ & 0.443 & 0.641 & $14 \backslash 14$ & 0.457 & 0.541 & $17 / 5$ & 0.395 & 0.481 \\
\hline 1 & 0.578 & 0.638 & $6 / 2$ & 0.560 & 0.615 & $14 / 15$ & 0.585 & 0.544 & $17 / 6$ & 0.464 & 0.402 \\
\hline 2 & & & $6 / 3$ & 0.396 & 0.427 & $14 / 16$ & 0.528 & 0.483 & 18 & & \\
\hline $2 / 1$ & 0.411 & 0.690 & $6 / 4$ & 0.572 & 0.391 & $14 / 17$ & 0.679 & 0.572 & $18 / 1$ & 0.471 & 0.394 \\
\hline $2 \backslash 2$ & & & $6 / 5$ & 0.435 & 0.435 & $14 / 18$ & 0.679 & 0.647 & $18 / 2$ & 0.390 & 0.583 \\
\hline $2 / 2 / 1$ & 0.608 & 0.566 & $6 \backslash 6$ & 0.442 & 0.398 & $14 / 19$ & 0.396 & 0.533 & $18 / 3$ & 0.397 & 0.481 \\
\hline $2 \backslash 2 \backslash 2$ & 0.525 & 0.677 & $6 / 7$ & 0.597 & 0.430 & $14 / 20$ & 0.399 & 0.487 & $18 / 4$ & 0.393 & 0.461 \\
\hline $2 / 2 / 3$ & 0.567 & 0.524 & $6 / 8$ & 0.551 & 0.590 & $14 / 21$ & 0.715 & 0.406 & $18 / 5$ & 0.418 & 0.448 \\
\hline $2 / 2 / 4$ & 0.754 & 0.475 & 7 & 0.497 & 0.581 & 15 & & & $18 / 6$ & 0.687 & 0.774 \\
\hline $2 / 2 / 5$ & 0.475 & 0.552 & 8 & 0.425 & 0.484 & $15 / 1$ & 0.391 & 0.395 & $18 / 7$ & 0.392 & 0.395 \\
\hline $2 / 2 / 6$ & 0.549 & 0.475 & 9 & & & $15 / 2$ & 0.485 & 0.488 & $18 / 8$ & 0.467 & 0.545 \\
\hline 3 & & & $9 / 1$ & 0.568 & 0.523 & $15 / 3$ & 0.433 & 0.421 & $18 / 9$ & 0.465 & 0.548 \\
\hline $3 / 1$ & 0.567 & 0.524 & $9 / 2$ & 0.419 & 0.612 & $15 / 4$ & 0.416 & 0.427 & $18 / 10$ & 0.524 & 0.476 \\
\hline $3 / 2$ & 0.452 & 0.404 & $9 / 3$ & 0.419 & 0.587 & $15 / 5$ & 0.391 & 0.443 & $18 / 11$ & 0.630 & 0.592 \\
\hline $3 \backslash 3$ & 0.485 & 0.459 & $9 / 4$ & 0.473 & 0.473 & $15 / 6$ & 0.430 & 0.460 & $18 / 12$ & 0.556 & 0.554 \\
\hline $3 / 4$ & 0.555 & 0.709 & 10 & 0.427 & 0.427 & $15 / 7$ & 0.394 & 0.515 & $18 / 13$ & 0.582 & 0.572 \\
\hline $3 / 5$ & & & 11 & 0.755 & 0.446 & $15 / 8$ & 0.585 & 0.441 & $18 / 14$ & 0.607 & 0.464 \\
\hline $3 / 5 / 1$ & 0.487 & 0.407 & 12 & 0.431 & 0.395 & $15 / 9$ & 0.424 & 0.392 & $18 / 15$ & 0.392 & 0.444 \\
\hline $3 / 5 / 2$ & & & 13 & 0.525 & 0.398 & $15 / 10$ & 0.431 & 0.394 & $18 / 16$ & 0.395 & 0.399 \\
\hline $3 / 5 / 2 / 1$ & 0.761 & 0.729 & \multicolumn{2}{|c|}{ Third axis } & & 16 & & & $18 / 17$ & 0.395 & 0.749 \\
\hline $3 / 5 / 2 / 2$ & 0.504 & 0.404 & 14 & & & $16 / 1$ & 0.450 & 0.543 & $18 \backslash 18$ & 0.427 & 0.447 \\
\hline $3 / 6$ & & & $14 / 1$ & 0.591 & 0.516 & $16 / 2$ & 0.457 & 0.541 & 19 & & \\
\hline $3 / 6 / 1$ & 0.440 & 0.479 & $14 / 2$ & 0.567 & 0.529 & $16 / 3$ & 0.553 & 0.421 & $19 / 1$ & 0.590 & 0.552 \\
\hline $3 / 6 / 2$ & 0.771 & 0.647 & $14 / 3$ & 0.423 & 0.392 & $16 / 4$ & 0.478 & 0.408 & $19 / 2$ & 0.516 & 0.514 \\
\hline 4 & & & $14 / 4$ & 0.397 & 0.614 & $16 / 5$ & & & $19 / 3$ & 0.542 & 0.532 \\
\hline $4 / 1$ & 0.504 & 0.526 & $14 / 5$ & 0.422 & 0.399 & $16 / 5 / 1$ & 0.647 & 0.734 & $19 / 4$ & 0.567 & 0.424 \\
\hline $4 / 2$ & 0.755 & 0.682 & $14 / 6$ & 0.557 & 0.400 & $16 / 5 / 2$ & 0.552 & 0.395 & $19 / 5$ & 0.452 & 0.404 \\
\hline $4 / 3$ & 0.396 & 0.611 & $14 / 7$ & 0.506 & 0.392 & $16 / 5 / 3$ & 0.527 & 0.505 & $19 / 6$ & 0.485 & 0.399 \\
\hline $4 \backslash 4$ & 0.450 & 0.511 & $14 / 8$ & 0.403 & 0.601 & $16 / 5 / 4$ & 0.625 & 0.608 & $19 / 7$ & 0.555 & 0.709 \\
\hline $4 / 5$ & 0.575 & 0.465 & $14 / 9$ & 0.520 & 0.575 & $16 / 5 / 5$ & 0.684 & 0.636 & $19 / 8$ & 0.397 & 0.507 \\
\hline $4 / 6$ & 0.392 & 0.692 & $14 / 10$ & 0.586 & 0.487 & & & & 20 & & \\
\hline $4 / 7$ & 0.398 & 0.543 & $14 / 11$ & & & Fo & axis & & $20 / 1$ & 0.590 & 0.552 \\
\hline $4 / 8$ & 0.574 & 0.697 & $14 / 11 / 1$ & 0.552 & 0.451 & 17 & 0.573 & 0.461 & $20 / 2$ & 0.590 & 0.552 \\
\hline $4 / 9$ & 0.431 & 0.413 & $14 / 11 / 2$ & 0.395 & 0.395 & $17 / 1$ & 0.456 & 0.467 & $20 / 3$ & 0.542 & 0.532 \\
\hline Seco & xis & & $14 / 11 / 3$ & 0.402 & 0.398 & $17 / 2$ & 0.431 & 0.483 & $20 / 4$ & 0.567 & 0.424 \\
\hline 5 & 0.546 & 0.432 & $14 / 12$ & 0.557 & 0.390 & $17 / 3$ & 0.470 & 0.500 & & & \\
\hline 6 & & & $14 / 13$ & 0.511 & 0.550 & $17 / 4$ & 0.434 & 0.555 & & & \\
\hline
\end{tabular}

Rg value $(24,0.05)=0.388$

It is clear from Table (1) the rise in the values of the internal consistency coefficient, and these values are significant at (0.05) level, which indicates the validity of the axes statements.

The stability of the exploratory form: The researcher followed the SpearmanBrown half-split method, the Gettmann equation, and the Alpha-Kronbach stability coefficient to calculate the stability of the questionnaire, as in Table (2). 
Table (2): Stability of the questionnaire by half-split and Alpha Kronbach method

\begin{tabular}{|c|c|c|c|}
\hline \multirow[b]{2}{*}{ Axes } & \multicolumn{2}{|c|}{ Half-split } & \multirow{2}{*}{$\begin{array}{c}\text { Alpha } \\
\text { Kronbach }\end{array}$} \\
\hline & $\begin{array}{c}\text { Spearman } \\
\text { Brown } \\
\end{array}$ & Gettman & \\
\hline $\begin{array}{l}\text { First axis: Determine the current state of the sports } \\
\text { facilities and the factors of Luxor Governorate. }\end{array}$ & 0.774 & 0.739 & 0.784 \\
\hline $\begin{array}{c}\text { Second axis: The role of officials in stimulating sport } \\
\text { tourism in Luxor. }\end{array}$ & 0.750 & 0.784 & 0.760 \\
\hline $\begin{array}{l}\text { Third axis: The importance of establishing a stadium } \\
\text { and its effect on promoting sports tourism and the } \\
\text { target audience for its establishment. }\end{array}$ & 0.730 & 0.760 & 0.743 \\
\hline $\begin{array}{l}\text { Fourth axis: the capabilities required to establish a } \\
\text { stadium in Luxor Governorate. }\end{array}$ & 0.731 & 0.740 & 0.811 \\
\hline The total score for the questionnaire & 0.762 & 0.790 & 0.872 \\
\hline
\end{tabular}

From Table (2), it is clear that the coefficient of stability in the half-split method ranged between (0.730) and (0.790), and that the alpha-Kronbach stability coefficient ranged between (0.743) and (0.872), which indicates that the questionnaire under consideration has a high stability coefficient.

From the above, the researcher reached the final form of the survey questionnaire

- Feasibility study form for establishing a sports stadium to stimulate sport tourism in Luxor.

Through the results of the exploratory form, the researcher confirmed the possibility of conducting a detailed study to establish a sports stadium to stimulate sports tourism in Luxor Governorate.

\section{Scientific transactions of the feasibility study form, validation of the content:}

The axes and statements were presented to a group of experts, whose number reached (50) experts from the academic and technical specialists in the sports field.

Table (3) Iterations, Percentages, and Loch Coeff. for the opinions of experts on the first axis Technical feasibility study for establishing a stadium to stimulate sport tourism in Luxor $(n=50)$

\begin{tabular}{|c|c|c|c|c|}
\hline \multirow{3}{*}{$\mathbf{n}$} & \multirow{3}{*}{ Statements } & \multicolumn{3}{|c|}{ Officials } \\
\hline & & \multicolumn{2}{|c|}{$\begin{array}{l}\text { Experts } \\
\text { approve }\end{array}$} & \multirow{2}{*}{$\begin{array}{c}\text { Loch } \\
\text { Coeff. }\end{array}$} \\
\hline & & No. & $\%$ & \\
\hline 1 & Choosing the suitable site for establishing the sports stadium in Luxor Governorate. & 50 & 100 & 1,000 \\
\hline 2 & Study the quality of the soil and its suitability for the nature of the project. & 50 & 100 & $\mathbf{1 , 0 0 0}$ \\
\hline 3 & $\begin{array}{l}\text { The area that the sports stadium will occupy is } 25 \text { acres }(25 \times 24 \text { karats) (with a total } \\
\text { of } 600 \text { karats) (600 karats } \times 175 \text { meters) with a total of approximately }(105,000) \text { square } \\
\text { meters. }\end{array}$ & 40 & 80 & 0.600 \\
\hline 4 & The area that the stadium will occupy $(120 \mathrm{mx} 70 \mathrm{~m})$ approx. & 50 & 100 & $\mathbf{1 , 0 0 0}$ \\
\hline \multirow[t]{7}{*}{5} & Specifications of the proposed sports stadium: & 30 & 60 & 0.200 \\
\hline & $\begin{array}{l}5 / 1 \text { - The auditoriums accommodate about }(80,000) \text { thousand spectators, divided into } \\
\text { the first, second and third grades. }\end{array}$ & 50 & 100 & $\mathbf{1 , 0 0 0}$ \\
\hline & 5/2- A auditorium designated for people with special needs (300) seats. & 50 & 100 & 1,000 \\
\hline & $5 / 3$ - booth with balcony for VIP visitors $(250)$. & 50 & 100 & 1,000 \\
\hline & 5/4 - Presidential District (1). & 50 & 100 & $\mathbf{1 , 0 0 0}$ \\
\hline & $5 / 5$ - Hall for VIP visitors (1). & 50 & 100 & $\mathbf{1 , 0 0 0}$ \\
\hline & 5/6 - Hall for press conferences, with a capacity of (120 persons). & 46 & 92 & 0.840 \\
\hline
\end{tabular}


Table (3) Iterations, Percentages, and Loch Coeff. for the opinions of experts on the first axis

Technical feasibility study for establishing a stadium to stimulate sport tourism in Luxor $(\mathbf{n}=50)$

\begin{tabular}{|c|c|c|c|}
\hline 5/7 - A booth attached to the conference room for simultaneous interpretation (4). & 48 & 96 & 0.920 \\
\hline 5/8 - Stadium lighting towers (4). & 49 & 98 & 0.960 \\
\hline 5/9 - A place for players and journalists (120 persons). & 50 & 100 & $\mathbf{1 , 0 0 0}$ \\
\hline $5 / 10$ - Lockers for players (4). & 50 & 100 & $\mathbf{1 , 0 0 0}$ \\
\hline 5/11- Rooms for Referees (2). & 50 & 100 & $\mathbf{1 , 0 0 0}$ \\
\hline 5/12 - Dope detecting rooms (1). & 50 & 100 & 1,000 \\
\hline 5/13 - Cabins for broadcasters (Radio and Television, accommodate (8) individuals). & 50 & 100 & $\mathbf{1 , 0 0 0}$ \\
\hline $5 / 14$ - Control room for radio and sound (2). & 46 & 92 & $\mathbf{0 . 8 4 0}$ \\
\hline 5/15- Cafeterias equipped with all capabilities (2). & 48 & 96 & 0.920 \\
\hline 5/16 - Guesthouse (1). & 45 & 90 & 0.800 \\
\hline $\begin{array}{l}\text { 5/17- Office of Members for the International Federation and the Organizing } \\
\text { Committee (1). }\end{array}$ & 50 & 100 & $\mathbf{1 , 0 0 0}$ \\
\hline 5/18 - Administrative offices (6). & 40 & 80 & 0.600 \\
\hline 5/19 - Meeting Hall (2). & 50 & 100 & $\mathbf{1 , 0 0 0}$ \\
\hline 5/20 - A media center equipped with Internet (1). & 50 & 100 & $\mathbf{1 , 0 0 0}$ \\
\hline 5/21 - Electronic gates $(20)$. & 46 & 92 & 0.840 \\
\hline 5/21/1 - for VIPs and officials (1). & 46 & 92 & 0.840 \\
\hline $5 / 21 / 2$ - for the participating teams, referees and organizing committee (1). & 45 & 90 & 0.800 \\
\hline $5 / 21 / 3$ - for media professionals and journalists (1). & 50 & 100 & $\mathbf{1 , 0 0 0}$ \\
\hline $5 / 21 / 4$ - for the first class audience, right of the compartment (1). & 49 & 98 & 0.960 \\
\hline $5 / 21 / 5$ - for the first class audience, left of the compartment (1). & 50 & 100 & $\mathbf{1 , 0 0 0}$ \\
\hline $5 / 21 / 6$ - for the second class audience,right of the compartment (2). & 41 & 82 & 0.640 \\
\hline $5 / 21 / 7$ - for the second class audience, left of the compartment (2). & 42 & 84 & 0.680 \\
\hline $5 / 21 / 8$ - for the third class audience, right of the compartment (5). & 43 & 86 & 0.720 \\
\hline $5 / 21 / 9$ - for a third class audience, left of the compartment (5). & 50 & 100 & 1,000 \\
\hline 5/22 - Waiting places for the main compartment and first class (1). & 50 & 100 & $\mathbf{1 , 0 0 0}$ \\
\hline $5 / 23$ - Parking spaces $(3)$ & 46 & 92 & 0.840 \\
\hline 5/24 - Physiotherapy Center (1). & 46 & 92 & 0.840 \\
\hline 5/25 - Therapeutic unit (1). & 48 & 96 & 0.920 \\
\hline $5 / 26$ - Storage (2). & 49 & 98 & 0.960 \\
\hline 5/27 - Toilets for the audience (10). & 48 & 96 & $\mathbf{0 . 9 2 0}$ \\
\hline 5/28 Electricity Control Room (2). & 47 & 94 & $\mathbf{0 . 8 8 0}$ \\
\hline Estimating the basic needs of machinery, equipment and furniture: & 48 & 96 & 0.920 \\
\hline $\begin{array}{l}\text { 6/1- An electronic scoreboard (2) on both sides of the stadium, with the latest } \\
\text { technology. }\end{array}$ & 49 & 98 & 0.960 \\
\hline 6/2 - A large TV screen $32 \mathrm{~m} \times 15 \mathrm{~m}(2)$ & $\mathbf{5 0}$ & 100 & $\mathbf{1 , 0 0 0}$ \\
\hline 6/3 - Communications near the main compartment (1). & 50 & 100 & 1,000 \\
\hline 6/4 - Internal and external communication devices. & 50 & 100 & $\mathbf{1 , 0 0 0}$ \\
\hline 6/5 - Computers (5). & 42 & 84 & 0.680 \\
\hline 6/6 - Printers (4). & 50 & 100 & $\mathbf{1 , 0 0 0}$ \\
\hline 6/7 - Photographic paper machines (2). & 50 & 100 & $\mathbf{1 , 0 0 0}$ \\
\hline 6/8 - Internal and external speakers (30). & 50 & 100 & 1,000 \\
\hline 6/9 - Surveillance Cameras (30) & 45 & 90 & 0.800 \\
\hline 6/10 - Alarm devices (60) & 47 & 94 & $\mathbf{0 . 8 8 0}$ \\
\hline 6/11 - Cables and equipment required for cameras and TV broadcasters (30). & 46 & 92 & $\mathbf{0 . 8 4 0}$ \\
\hline 6/12 - Electricity generators. (6). & 50 & 100 & $\mathbf{1 , 0 0 0}$ \\
\hline $6 / 13$ - $(80)$ thousand seats for the audience $(80000)$. & 50 & 100 & $\mathbf{1 , 0 0 0}$ \\
\hline 6/14 - Seats for people with special needs (300) seats. & 50 & 100 & 1,000 \\
\hline 6/15 - Seats for players and journalists (120). & 50 & 100 & $\mathbf{1 , 0 0 0}$ \\
\hline 6/16 - Seats for VIP visitors in the compartment $(250)$. & 50 & 100 & 1,000 \\
\hline 6/17 - Seats for players and administrators (120) seats divided into two teams. & 50 & 100 & 1,000 \\
\hline 6/18 - Offices (50). & 46 & 92 & 0.840 \\
\hline 6/19 - Administrative Cabinets (50). & $\mathbf{5 0}$ & 100 & $\mathbf{1 , 0 0 0}$ \\
\hline
\end{tabular}


Table (3) Iterations, Percentages, and Loch Coeff. for the opinions of experts on the first axis Technical feasibility study for establishing a stadium to stimulate sport tourism in Luxor $(\mathbf{n}=\mathbf{5 0})$

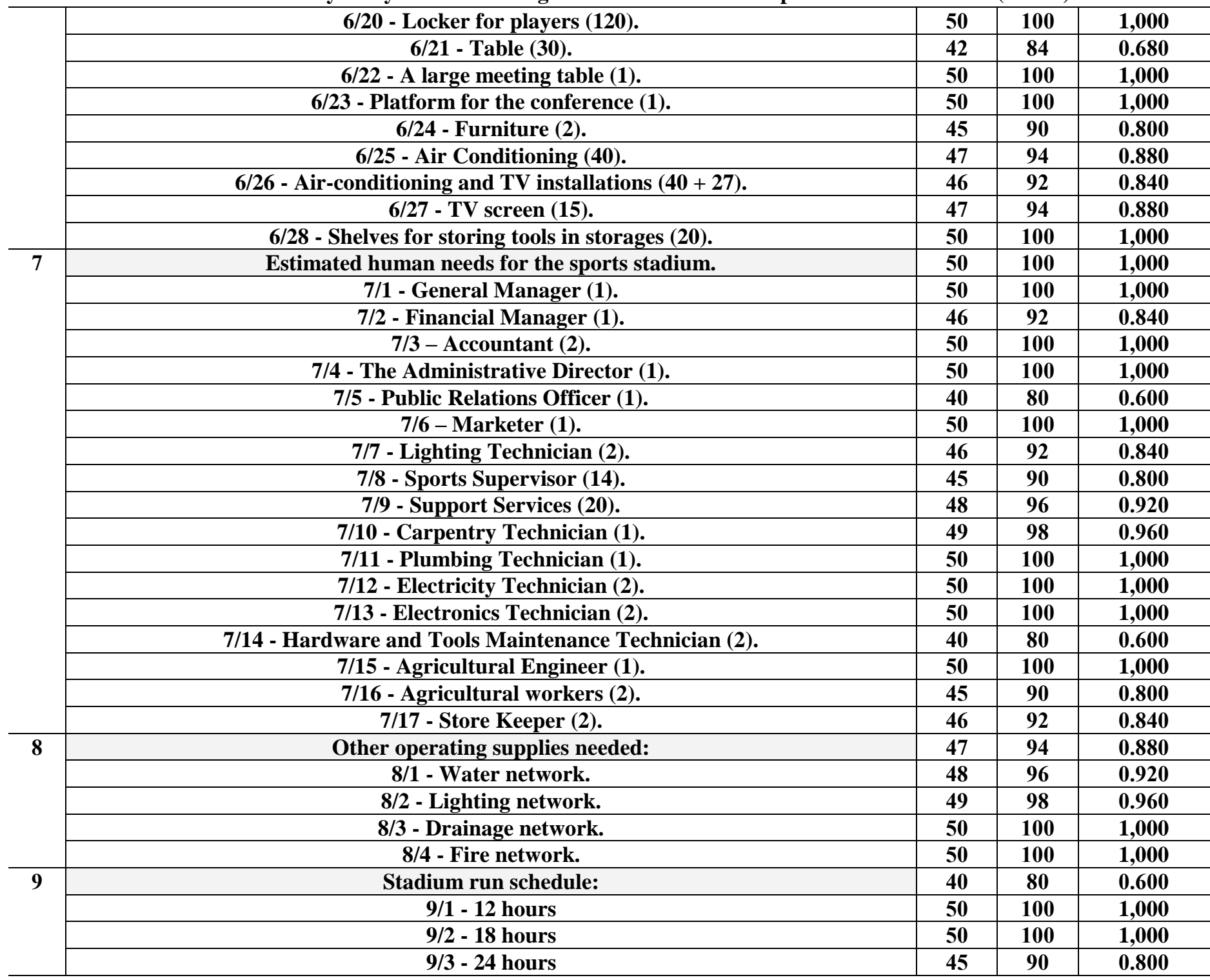

Statistically acceptable minimum Loch coefficient at $(n=50$ expert $)=0.280$ 
Table (4) Iterations, Percentages, and Loch coefficient for the opinions of experts on the second axis Financial feasibility study for establishing a sports stadium to stimulate sport tourism in Luxor Governorate $(\mathbf{n}=\mathbf{5 0})$

\begin{tabular}{|c|c|c|c|c|}
\hline \multirow{3}{*}{$\mathbf{N}$} & \multirow{3}{*}{ Statements } & \multicolumn{3}{|c|}{ Officials } \\
\hline & & \multicolumn{2}{|c|}{$\begin{array}{l}\text { Experts } \\
\text { approve }\end{array}$} & \multirow{2}{*}{$\begin{array}{l}\text { Loch } \\
\text { Coeff. }\end{array}$} \\
\hline & & No. & $\%$ & \\
\hline \multirow[t]{9}{*}{10} & $\begin{array}{l}\text { Exchange items for the establishment of the sports stadium in Luxor } \\
\text { Governorate: }\end{array}$ & $\mathbf{5 0}$ & 100 & 1,000 \\
\hline & 10/1 - The engineering design of the stadium. & $\mathbf{5 0}$ & 100 & $\mathbf{1 , 0 0 0}$ \\
\hline & 10/2 - Infrastructure. & 50 & 100 & 1,000 \\
\hline & 10/3 - Attachments attached to the sports stadium. & 50 & 100 & 1,000 \\
\hline & 10/4 - Furniture. & 50 & 100 & $\mathbf{1 , 0 0 0}$ \\
\hline & 10/5 - Tools and equipment. & 45 & 90 & 0.800 \\
\hline & 10/6 - Electricity, water and drainage. & 46 & 92 & 0.840 \\
\hline & 10/7 - Pharaonic decorations and architectural designs. & 47 & 94 & $\mathbf{0 . 8 8 0}$ \\
\hline & 10/8 - Roses, gardens, and entrance trees. & 50 & 100 & $\mathbf{1 , 0 0 0}$ \\
\hline \multirow[t]{6}{*}{11} & Operating exchange items for the sports stadium in Luxor Governorate: & 50 & 100 & $\mathbf{1 , 0 0 0}$ \\
\hline & 11/1 - Salaries for employees for a year (60 employees). & 50 & 100 & 1,000 \\
\hline & 11/2 - Administrative expenses. & 42 & 84 & 0.680 \\
\hline & 11/3 - Stationery and office supplies. & 50 & 100 & 1,000 \\
\hline & 11/4 - Maintenance at $10 \%$ of equipment costs. & 48 & 96 & 0.920 \\
\hline & 11/5 - Depreciation is $10 \%$ of equipment costs. & 49 & 98 & 0.960 \\
\hline \multirow[t]{6}{*}{12} & Marketing exchange items for the sports stadium in Luxor Governorate: & 45 & 90 & 0.800 \\
\hline & 12/1 - Designing a website for the stadium. & 50 & 100 & $\mathbf{1 , 0 0 0}$ \\
\hline & 12/2 - An advertising campaign about the stadium and its activities. & 50 & 100 & 1,000 \\
\hline & 12/3 - Guide to activities, sporting events and tourist sites in the governorate. & 50 & 100 & 1,000 \\
\hline & $\begin{array}{l}\text { 12/4 - An electronic and paper sports magazine on the stadium and tourism in } \\
\text { the governorate. }\end{array}$ & 50 & 100 & 1,000 \\
\hline & 12/5 - Banners on the stadium in the country. & 50 & 100 & 1,000 \\
\hline \multirow[t]{11}{*}{13} & Estimate the return from establishing a sports stadium in Luxor Governorate: & 45 & 90 & 0.800 \\
\hline & 13/1 - Ticket sales, matches and competitions. & 46 & 92 & $\mathbf{0 . 8 4 0}$ \\
\hline & 13/2 - Organizing paid sports events. & 50 & 100 & $\mathbf{1 , 0 0 0}$ \\
\hline & 13/3 - VIP seats. & 50 & 100 & 1,000 \\
\hline & 13/4 - Holding conferences. & 50 & 100 & 1,000 \\
\hline & 13/5 - Return from the Physiotherapy Center. & 42 & 84 & 0.680 \\
\hline & 13/6 - Advertisements and corporate sponsorship. & 50 & 100 & 1,000 \\
\hline & 13/7 - The championship companies. & 45 & 90 & 0.800 \\
\hline & 13/8 - Stadium rental for various sporting events. & 46 & 92 & 0.840 \\
\hline & 13/9 - Tourists who follow sporting events. & 47 & 94 & $\mathbf{0 . 8 8 0}$ \\
\hline & 13/10 - Support from the Ministry of Youth and Sports. & 48 & 96 & 0.920 \\
\hline
\end{tabular}

Statistically acceptable minimum Loch coefficient at $(n=50$ expert $)=0.280$ 
Table (5) Iterations, Percentages, and Loch Coeff. for the opinions of experts on the third axis, the marketing feasibility study for establishing a sports stadium to stimulate sport tourism in

Luxor Governorate $(\mathbf{n}=\mathbf{5 0})$

\begin{tabular}{|c|c|c|c|c|}
\hline \multirow{3}{*}{$\mathbf{N}$} & \multirow{3}{*}{ Statements } & \multicolumn{3}{|c|}{ Officials } \\
\hline & & \multicolumn{2}{|c|}{$\begin{array}{l}\text { Experts } \\
\text { approve }\end{array}$} & \multirow{2}{*}{$\begin{array}{l}\text { Loch } \\
\text { Coeff }\end{array}$} \\
\hline & & No. & $\%$ & \\
\hline \multirow[t]{3}{*}{14} & Create a recreational plan for the Sports Stadium by the Ministry: & 50 & 100 & $\mathbf{1 , 0 0 0}$ \\
\hline & $14 / 1$ - Youth and Sports & 40 & 80 & 0.600 \\
\hline & 14/2-Tourism & 50 & 100 & $\mathbf{1 , 0 0 0}$ \\
\hline 15 & $\begin{array}{l}\text { Create a website with all the information about the stadium, the event and } \\
\text { the tourist places. }\end{array}$ & 50 & 100 & 1,000 \\
\hline 16 & $\begin{array}{l}\text { Work to attract sponsors for the activities organized in the stadium to } \\
\text { achieve the largest return. }\end{array}$ & 50 & 100 & $\mathbf{1 , 0 0 0}$ \\
\hline 17 & Connecting the website to various sports sites. & 45 & 90 & $\mathbf{0 . 8 0 0}$ \\
\hline 18 & $\begin{array}{l}\text { Issuing an electronic and sports sports magazine indicating the stadium } \\
\text { and its activities. }\end{array}$ & 46 & 92 & 0.840 \\
\hline 19 & Advertising by various advertising methods and websites. & 47 & 94 & $\mathbf{0 . 8 8 0}$ \\
\hline 20 & $\begin{array}{l}\text { Contracting with advertising and promotional companies to promote the } \\
\text { stadium and its activities. }\end{array}$ & 50 & 100 & 1,000 \\
\hline \multirow[t]{5}{*}{21} & $\begin{array}{l}\text { Carrying out a market study of the environment surrounding the sports } \\
\text { stadium on: }\end{array}$ & 40 & 80 & 0.600 \\
\hline & 21/1 - Population density. & 50 & 100 & $\mathbf{1 , 0 0 0}$ \\
\hline & 21/2 - Average per capita income. & 50 & 100 & $\mathbf{1 , 0 0 0}$ \\
\hline & 21/3 - Advanced commercial activity in the region. & 50 & 100 & 1,000 \\
\hline & 21/4 - Changes that can affect family expenses. & 45 & 90 & 0.800 \\
\hline \multirow[t]{3}{*}{22} & Create a guide that includes: & 46 & 92 & 0.840 \\
\hline & 22/1 - Activities and sporting events organized by the stadium. & 47 & 94 & 0.880 \\
\hline & 22/2 - Available tourist sites in the governorate. & 48 & 96 & 0.920 \\
\hline \multirow[t]{7}{*}{23} & Using different advertising methods to market the sports stadium through: & 31 & 62 & 0.240 \\
\hline & 23/1 - Use of advertising signs in the country. & 40 & 80 & 0.600 \\
\hline & 23/2 - The official channel of the state. & 50 & 100 & $\mathbf{1 , 0 0 0}$ \\
\hline & 23/3 - Providing an overview of the stadium in sports programs. & 50 & 100 & $\mathbf{1 , 0 0 0}$ \\
\hline & 23/4 - Place it within the tourist program of tourist companies. & 50 & 100 & 1,000 \\
\hline & 23/4 - Main roads. & 46 & 92 & 0.840 \\
\hline & 23/6 - Leaflets and posters linking the event to tourism. & 48 & 96 & 0.920 \\
\hline
\end{tabular}

Statistically acceptable minimum Loch coefficient at $(n=50$ expert $)=0.280$

Table (6) iterations, percentages and loch coeff. for the opinions of the experts on the fourth axis,

the social feasibility study to establish a stadium to stimulate sports tourism in Luxor. $(\mathrm{N}=50)$

\begin{tabular}{|c|c|c|c|c|}
\hline \multirow{3}{*}{$\mathbf{N}$} & \multirow{3}{*}{ Statements } & \multicolumn{3}{|c|}{ Officials } \\
\hline & & \multicolumn{2}{|c|}{$\begin{array}{l}\text { Experts } \\
\text { approve }\end{array}$} & \multirow{2}{*}{$\begin{array}{l}\text { Experts } \\
\text { approve }\end{array}$} \\
\hline & & No. & $\%$ & \\
\hline 24 & $\begin{array}{c}\text { Providing job opportunities for the Egyptians in general and the } \\
\text { governorate in particular. }\end{array}$ & 50 & 100 & 1,000 \\
\hline 25 & Increased national income due to the operation of the stadium. & 50 & 100 & 1,000 \\
\hline 26 & $\begin{array}{l}\text { Achieve a social benefit for the province and put it on the map of } \\
\text { sports tourism. }\end{array}$ & 43 & 86 & 0.720 \\
\hline 27 & Intercultural exchange between peoples due to sports meetings. & 50 & 100 & 1,000 \\
\hline
\end{tabular}

Statistically acceptable minimum Loch coefficient at $(n=50$ expert $)=0.280$ 
Table (7) Frequencies, Percentages, and Loch Coeff. for the opinions of experts on the fifth axis: The legal feasibility study for establishing a sports stadium to stimulate sport tourism in Luxor Governorate $(\mathbf{n}=\mathbf{5 0})$

\begin{tabular}{|c|c|c|c|c|}
\hline \multirow{3}{*}{$\mathbf{N}$} & \multirow{3}{*}{ Statements } & \multicolumn{3}{|c|}{ Officials } \\
\hline & & \multicolumn{2}{|c|}{$\begin{array}{l}\text { Experts } \\
\text { approve }\end{array}$} & \multirow{2}{*}{$\begin{array}{l}\text { Experts } \\
\text { approve }\end{array}$} \\
\hline & & No. & $\%$ & \\
\hline 28 & Determine the legal entity of the stadium. & 50 & 100 & $\mathbf{1 , 0 0 0}$ \\
\hline 29 & Determine the permitted areas to invest in the stadium. & 50 & 100 & $\mathbf{1 , 0 0 0}$ \\
\hline 30 & $\begin{array}{l}\text { Identify the competent authorities to supervise the project, the Ministry of } \\
\text { Youth and Sports. }\end{array}$ & 41 & 82 & 0.640 \\
\hline 31 & Determine who is responsible for building the stadium. & 41 & 82 & 0.640 \\
\hline 32 & Establish a timetable for the stages of implementing the sports stadium. & 50 & 100 & $\mathbf{1 , 0 0 0}$ \\
\hline 33 & $\begin{array}{l}\text { Setting procedures in violation of the handover stages to create the } \\
\text { stadium. }\end{array}$ & 45 & 90 & 0.800 \\
\hline 34 & Implementation within the specified time stipulated in the contract. & 46 & 92 & 0.840 \\
\hline 35 & The obligation to pay the taxes due and all government dues. & 47 & 94 & 0.880 \\
\hline 36 & Make all licenses for the sports stadium project. & 50 & 100 & 1,000 \\
\hline
\end{tabular}
Statistically acceptable minimum Loch coefficient at $(n=50$ expert $)=0.280$

From tables (3:7), it is clear that the percentage of experts agreeing on the axes statements is significant according to the Loach coeff., and the statements were accepted from the experts agreement on them.

Statistical processing: The researcher used statistical processes appropriate to the nature of the research. 
Review and discussion of the results "First, the results of the first axis:

Table (8) results of iterations, weighting ratio, average value, prevailing direction, and value Chi to indicate the differences between (research categories) and (research group) to respond to the first axis

\begin{tabular}{|c|c|c|c|c|c|c|c|c|c|c|c|c|c|c|c|c|c|c|c|c|c|c|}
\hline \multirow{2}{*}{$\mathbf{N}$} & \multirow{2}{*}{ Statements } & \multicolumn{6}{|c|}{ Officials and workers of the Ministry of Youth and Sports = 83} & \multicolumn{6}{|c|}{ Officials and workers of the Ministry of Tourism $=68$} & \multicolumn{6}{|c|}{ Academic professors $=17$} & \multicolumn{3}{|c|}{ Research group } \\
\hline & & Yes & Maybe & No & W.R. & Avg. & Dir. & Yes & Maybe & No & W.R. & Avg. & Dir. & Yes & Maybe & No & W.R. & Avg. & Dir. & W.R. & Dir. & Chi \\
\hline 1 & $\begin{array}{l}\text { There are sports facilities in Luxor that } \\
\text { can be used for sports tourism. }\end{array}$ & 4 & 4 & 75 & 38.15 & 1.14 & No & 10 & 9 & 49 & 47.55 & 1.43 & No & $\mathbf{0}$ & 2 & 15 & 37.25 & 1.12 & No & 41.87 & No & $* 10.68$ \\
\hline 2 & $\begin{array}{l}\text { The current sports facilities in the } \\
\text { governorate are valid for: }\end{array}$ & & & & & & & & & & & & & & & & & & & & & \\
\hline $2 / 1$ & To serve sport tourism in Luxor. & $\mathbf{0}$ & 11 & 72 & 37.75 & 1.13 & No & 9 & 8 & 51 & 46.08 & 1.38 & No & $\mathbf{0}$ & 2 & 15 & 37.25 & 1.12 & No & 41.07 & No & $* 14.02$ \\
\hline $2 \backslash 2$ & $\begin{array}{l}\text { Organizing local and international sports } \\
\text { competitions such as: }\end{array}$ & & & & & & No & & & & & & & & & & & & & & & \\
\hline 2/2/1 & $\begin{array}{l}\text { Establishing the Egyptian league } \\
\text { (Premier League competition A, B) }\end{array}$ & 5 & 13 & 65 & 42.57 & 1.28 & No & 5 & 11 & 52 & 43.63 & 1.31 & No & 6 & 2 & 9 & 60.78 & 1.82 & Maybe & 44.84 & No & $* 14.68$ \\
\hline $2 / 2 \backslash 2$ & Single sports tournaments. & 21 & 13 & 49 & $\mathbf{5 5 . 4 2}$ & 1.66 & No & 8 & 12 & 48 & 47.06 & 1.41 & No & 1 & 2 & 14 & 41.18 & 1.24 & No & $\mathbf{5 0 . 6 0}$ & No & *7.18 \\
\hline $2 / 2 / 3$ & Local tournaments. & 27 & 11 & 45 & 59.44 & 1.78 & Maybe & 10 & 17 & 41 & 51.47 & 1.54 & No & $\mathbf{0}$ & $\mathbf{0}$ & 17 & 33.33 & 1.00 & No & 53.57 & No & $* 20.65$ \\
\hline $2 / 2 / 4$ & Arab tournaments. & $\mathbf{0}$ & $\mathbf{0}$ & $\mathbf{8 3}$ & 33.33 & 1.00 & No & 3 & 6 & 59 & 39.22 & 1.18 & No & $\mathbf{0}$ & $\mathbf{0}$ & 17 & 33.33 & 1.00 & No & 35.71 & No & *13.98 \\
\hline $2 / 2 / 5$ & World Cup. & $\mathbf{0}$ & $\mathbf{0}$ & 83 & 33.33 & 1.00 & No & 7 & 2 & 59 & 41.18 & 1.24 & No & $\mathbf{0}$ & $\mathbf{0}$ & 17 & 33.33 & 1.00 & No & 36.51 & No & *13.98 \\
\hline $2 / 2 / 6$ & $\begin{array}{l}\text { African tournaments (clubs and national } \\
\text { teams). }\end{array}$ & $\mathbf{0}$ & $\mathbf{0}$ & 83 & 33.33 & 1.00 & No & $\mathbf{0}$ & $\mathbf{0}$ & 68 & $\mathbf{3 3 . 3 3}$ & 1.00 & No & $\mathbf{0}$ & $\mathbf{0}$ & 17 & 33.34 & 1.00 & No & 33.33 & No & 0.02 \\
\hline 3 & $\begin{array}{l}\text { Sports facilities in Luxor Governorate are } \\
\text { characterized by the following: }\end{array}$ & & & & & & & & & & & & & & & & & & & & & \\
\hline $3 / 1$ & Technical legal specifications. & 3 & 11 & 69 & 40.16 & 1.20 & No & 4 & 4 & $\mathbf{6 0}$ & 39.22 & 1.18 & No & $\mathbf{0}$ & 2 & 15 & 37.25 & 1.12 & No & 39.48 & No & 3.43 \\
\hline $3 / 2$ & Security and safety factors. & 4 & 13 & 66 & 41.77 & 1.25 & No & 4 & 3 & 61 & 38.73 & 1.16 & No & 3 & 3 & 11 & 50.98 & 1.53 & No & 41.47 & No & $* 9.65$ \\
\hline $3 \backslash 3$ & $\begin{array}{l}\text { It accommodates a large number of } \\
\text { audiences (100: 120) thousand. }\end{array}$ & $\mathbf{0}$ & 0 & 83 & 33.33 & 1.00 & No & $\mathbf{0}$ & $\mathbf{0}$ & 68 & $\mathbf{3 3 . 3 3}$ & 1.00 & No & 0 & $\mathbf{0}$ & 17 & 33.33 & 1.00 & No & 33.33 & No & 0.00 \\
\hline $3 / 4$ & $\begin{array}{l}\text { Sports tools to meet the needs of sport } \\
\text { tourism in Luxor. }\end{array}$ & $\mathbf{0}$ & 13 & 70 & 38.55 & 1.16 & No & $\mathbf{0}$ & 8 & 60 & 37.25 & 1.12 & No & $\mathbf{0}$ & $\mathbf{0}$ & 17 & 33.34 & 1.00 & No & 37.50 & No & 3.22 \\
\hline $3 / 5$ & Modern technological means: & & & & & & & & & & & & & & & & & & & & & \\
\hline $3 / 5 / 1$ & $\begin{array}{l}\text { Surveillance cameras inside the sports } \\
\text { facilities in the governorate. }\end{array}$ & 4 & 14 & 65 & 42.17 & 1.27 & No & 8 & 6 & 54 & 44.12 & 1.32 & No & $\mathbf{0}$ & 1 & 16 & 35.29 & 1.06 & No & 42.26 & No & $* 6.92$ \\
\hline $3 / 5 / 2$ & $\begin{array}{l}\text { Electronic screens equipped with } \\
\text { technological features: }\end{array}$ & & & & & & & & & & & & & & & & & & & & & \\
\hline $3 / 5 / 2 / 1$ & Ability of replaying events. & $\mathbf{0}$ & $\mathbf{0}$ & 83 & $\mathbf{3 3 . 3 3}$ & 1.00 & No & $\mathbf{0}$ & $\mathbf{0}$ & 68 & $\mathbf{3 3 . 3 3}$ & 1.00 & No & $\mathbf{0}$ & $\mathbf{0}$ & 17 & 33.34 & 1.00 & No & $\mathbf{3 3 . 3 3}$ & No & 0.01 \\
\hline $3 / 5 / 2 / 2$ & $\begin{array}{l}\text { Ability of viewing events at the same } \\
\text { time from other games. }\end{array}$ & $\mathbf{0}$ & $\mathbf{0}$ & 83 & 33.33 & 1.00 & No & $\mathbf{0}$ & $\mathbf{0}$ & 68 & $\mathbf{3 3 . 3 3}$ & 1.00 & No & $\mathbf{0}$ & $\mathbf{0}$ & 17 & 33.34 & 1.00 & No & 33.33 & No & 0.01 \\
\hline $3 / 6$ & Experienced workers aware of: & & & & & & & & & & & & & & & & & & & & & \\
\hline $3 / 6 / 1$ & $\begin{array}{l}\text { How to organize local and international } \\
\text { sports competitions. }\end{array}$ & 21 & 12 & 50 & 55.02 & 1.65 & No & 9 & 8 & 51 & 46.08 & 1.38 & No & 7 & $\mathbf{0}$ & 10 & 60.78 & 1.82 & Maybe & 51.98 & No & $* 9.48$ \\
\hline $3 / 6 / 2$ & Sports tourism concepts. & 3 & 12 & 68 & 40.56 & 1.22 & No & 5 & 2 & 61 & 39.22 & 1.18 & No & 10 & 5 & 2 & 82.35 & 2.47 & Yes & 44.25 & No & *62.13 \\
\hline
\end{tabular}

Chi value $(0.05)=5.99$ weighted avg: No $(1: 1.67)$, maybe $(1.68: 2.33)$, yes $(2.34: 3)$ 


\section{Continued table (8)}

\begin{tabular}{|c|c|c|c|c|c|c|c|c|c|c|c|c|c|c|c|c|c|c|c|c|c|c|}
\hline \multirow{2}{*}{$\mathbf{N}$} & \multirow{2}{*}{ Statements } & \multicolumn{6}{|c|}{ Officials and workers of the Ministry of Youth and Sports $=83$} & \multicolumn{6}{|c|}{ Officials and workers of the Ministry of Tourism $=68$} & \multicolumn{6}{|c|}{ Academic professors $=17$} & \multicolumn{3}{|c|}{ Research group } \\
\hline & & Yes & Maybe & No & W.R. & Avg. & Dir. & Yes & Maybe & No & W.R. & Avg. & Dir. & Yes & Maybe & No & W.R. & Avg. & Dir. & W.R. & Dir. & Chi \\
\hline 4 & $\begin{array}{l}\text { The factors that contribute to progress of } \\
\text { sports tourism in Luxor are: }\end{array}$ & & & & & & & & & & & & & & & & & & & & & \\
\hline $4 / 1$ & $\begin{array}{l}\text { Transportation network for moving to } \\
\text { and from sports practice areas. }\end{array}$ & 83 & $\mathbf{0}$ & $\mathbf{0}$ & 100.00 & 3.00 & Yes & 68 & $\mathbf{0}$ & $\mathbf{0}$ & 100.00 & 3.00 & Yes & 17 & $\mathbf{0}$ & $\mathbf{0}$ & 100.00 & $\mathbf{3 . 0 0}$ & Yes & 100 & Yes & 0.01 \\
\hline $4 / 2$ & $\begin{array}{l}\text { Road networks, airports and ports able } \\
\text { to bear the numbers of tourists }\end{array}$ & 83 & $\mathbf{0}$ & $\mathbf{0}$ & 100.00 & 3.00 & Yes & 68 & $\mathbf{0}$ & $\mathbf{0}$ & 100.00 & 3.00 & Yes & 17 & $\mathbf{0}$ & $\mathbf{0}$ & 100.00 & 3.00 & Yes & 100 & Yes & 0.01 \\
\hline $4 / 3$ & $\begin{array}{l}\text { Hotels that allow large numbers of } \\
\text { tourists to follow the sporting event. }\end{array}$ & 83 & $\mathbf{0}$ & $\mathbf{0}$ & 100.00 & 3.00 & Yes & 68 & $\mathbf{0}$ & $\mathbf{0}$ & 100.00 & 3.00 & Yes & 17 & $\mathbf{0}$ & $\mathbf{0}$ & 100.00 & 3.00 & Yes & 100 & Yes & 0.01 \\
\hline $4 \backslash 4$ & Free space for building a sports stadium. & 83 & $\mathbf{0}$ & $\mathbf{0}$ & 100.00 & 3.00 & Yes & 68 & $\mathbf{0}$ & $\mathbf{0}$ & 100.00 & 3.00 & Yes & 17 & $\mathbf{0}$ & $\mathbf{0}$ & 100.00 & 3.00 & Yes & 100 & Yes & 0.01 \\
\hline $4 / 6$ & Natural climate that attracts tourists. & 83 & $\mathbf{0}$ & $\mathbf{0}$ & 100.00 & 3.00 & Yes & 68 & $\mathbf{0}$ & $\mathbf{0}$ & 100.00 & 3.00 & Yes & 17 & $\mathbf{0}$ & $\mathbf{0}$ & 100.00 & 3.00 & Yes & 100 & Yes & 0.01 \\
\hline $4 / 7$ & $\begin{array}{l}\text { Archeological sites that express different } \\
\text { civilizations. }\end{array}$ & 83 & $\mathbf{0}$ & $\mathbf{0}$ & 100.00 & 3.00 & Yes & 68 & $\mathbf{0}$ & $\mathbf{0}$ & 100.00 & 3.00 & Yes & 17 & $\mathbf{0}$ & $\mathbf{0}$ & 100.00 & 3.00 & Yes & 100 & Yes & 0.01 \\
\hline $4 / 8$ & Monuments of many religions. & 83 & $\mathbf{0}$ & $\mathbf{0}$ & 100.00 & 3.00 & Yes & 68 & $\mathbf{0}$ & $\mathbf{0}$ & 100.00 & 3.00 & Yes & 17 & $\mathbf{0}$ & $\mathbf{0}$ & 100.00 & 3.00 & Yes & 100 & Yes & 0.01 \\
\hline $4 / 9$ & The Nile River. & 83 & $\mathbf{0}$ & $\mathbf{0}$ & 100.00 & 3.00 & Yes & 68 & $\mathbf{0}$ & $\mathbf{0}$ & 100.00 & 3.00 & Yes & 17 & $\mathbf{0}$ & $\mathbf{0}$ & 100.00 & 3.00 & Yes & 100 & Yes & 0.01 \\
\hline
\end{tabular}


It is clear from Table No. (8) that there are statistically significant differences at the level $(0.05)$ between the responses of the research categories to the statements $(1,2 / 1,2 / 2 / 2,2 / 2 / 4,2 / 2 / 5,3 / 2,3 / 5 / 1)$ where the opinions came in negative direction, and the value of Chi ranged between $(6.92 *: 14.02 *)$.

The results of the study of Khalifa Talib Behbani (2001) (21), Saber Hassan Omar (2006) (32), and Youssef Bin Attia Al-Thobiti (2010) confirm that it is considered one of the most important factors in sport tourism, the availability of governmental or private sports facilities to serve it, and that it is not done exploiting the facilities available in the country to serve sports tourism. Sports facilities are a major source of increased economic growth. (38: 138)

The researcher believes that sports tourism is one of the most important types of tourism that increases tourist attraction, so the country must provide all capabilities, tools, devices and places to organize local and international competitions, which has a great impact on raising the sports tourism.

While the responses came not statistically significant among the research categories about the statements $(2 / 2 / 6,3 / 1,3 / 3,3 / 4,3 / 5 / 2 / 1,3 / 5 / 2 / 2)$ where the responses were in the direction of no and Chi value was (0.02: 3.43).

Hassan Obaid Fahmy (2017) indicates that sports facilities must be equipped with all appropriate tools and devices to raise the level of service, including the use of surveillance cameras to follow the crowds. $(17: 11)$

The researcher believes that the state should strive to provide sports facilities that are in line with the requirements of sport tourism, taking into account that they are appropriate to the numbers of the public, and equip them with different tools that makes the work effective and professional.

It is clear that there are no statistically significant differences between responses of the research categories around statements $(4 / 1,4 / 2,4 / 3,4 / 5,4 / 6,4 / 7,4 / 8,4 / 9)$ in the yes direction, and Chi value $(0.01)$ for all statements.

Mohamed Hassan Mohamed (2015) and the official website of Luxor Governorate (2019) confirm that Luxor is one of the governorates with the most attractions such as natural factors and human factors. (40) (24:38)

The researcher believes that by focusing on the factors that contribute to the revitalization of sport tourism in Luxor, we can have the ability to host the major international championships.

It is clear that there are statistically significant differences between the responses of the category of officials and workers in the Ministry of Youth and Sports and the category of officials and workers in the Ministry of Tourism around the statements $(2 / 2 / 1,3 / 6 / 1)$ where responses of the two groups came in no direction while the opinions of academic professors were in maybe direction, and Chi value was (14.68 *) $(9.48 *)$, respectively.

Ibrahim Mahmoud Abdel Maqsoud and Hassan Ahmed El Shafei (2004) make it clear that the human factor specialized in the field of sport tourism is considered a qualified tourist workforce to meet the needs of the tourist labor market. $(20: 32)$

The results of Hamad Karam Al-Kaabi study (2012) (14) also confirm that there are no qualified human cadres to work in the field of sports tourism, in addition to the lack of a competent organization to graduate these cadres.

The researcher believes that sports leaders must rely on specialized and trained human power in order to host major championships and events on the land of Luxor Governorate. 
Table (9) Results of iterations, weighting ratio, average value, prevailing direction and value Chi to indicate the differences between (research categories) and (research group) to respond to the second axis

\begin{tabular}{|c|c|c|c|c|c|c|c|c|c|c|c|c|c|c|c|c|c|c|c|c|c|c|}
\hline \multirow{2}{*}{$\mathbf{N}$} & \multirow{2}{*}{ Statements } & \multicolumn{6}{|c|}{$\begin{array}{c}\text { Officials and workers of the Ministry of Youth } \\
\text { and Sports = 83 }\end{array}$} & \multicolumn{6}{|c|}{$\begin{array}{c}\text { Officials and workers of the Ministry of } \\
\text { Tourism }=68\end{array}$} & \multicolumn{6}{|c|}{ Academic professors = 17} & \multicolumn{3}{|c|}{ Research group } \\
\hline & & Yes & Maybe & No & W.R. & Avg. & Dir. & Yes & Maybe & No & W.R. & Avg. & Dir. & Yes & Maybe & No & W.R. & Avg. & Dir. & W.R. & Dir. & Chi \\
\hline 5 & $\begin{array}{l}\text { Government is interested in sport } \\
\text { tourism in Luxor. }\end{array}$ & 55 & 20 & 8 & 85.54 & 2.57 & Yes & 61 & 2 & 5 & 94.12 & 2.82 & Yes & 10 & 5 & 2 & 82.35 & 2.47 & Yes & 88.69 & Yes & $* 16.29$ \\
\hline 6 & $\begin{array}{l}\text { The ministries of tourism and sports are } \\
\text { cooperating on: }\end{array}$ & & & & & & & & & & & & & & & & & & & & & \\
\hline $6 / 1$ & $\begin{array}{l}\text { Development of the sport system in the } \\
\text { tourism field. }\end{array}$ & 40 & 21 & 22 & 73.90 & 2.22 & Maybe & 56 & 4 & 8 & 90.20 & 2.71 & Yes & 14 & 2 & 1 & 92.16 & 2.76 & Yes & 82.34 & Yes & $* 22.49$ \\
\hline $6 / 2$ & Promoting sport tourism. & 51 & 21 & 11 & 82.73 & 2.48 & Yes & 60 & 5 & 3 & 94.61 & 2.84 & Yes & 4 & 7 & 6 & 62.75 & 1.88 & Maybe & 85.52 & Yes & *31.24 \\
\hline $6 / 3$ & $\begin{array}{l}\text { Usage of natural, geographical and } \\
\text { archaeological components to attract } \\
\text { sport tourism in Luxor. }\end{array}$ & 57 & 16 & 10 & 85.54 & 2.57 & Yes & 61 & 3 & 4 & 94.61 & 2.84 & Yes & 9 & 3 & 5 & 74.51 & 2.24 & Maybe & 88.10 & Yes & $* 16.81$ \\
\hline $6 / 4$ & $\begin{array}{l}\text { Providing a system to attract tourists } \\
\text { towards sports tourism. }\end{array}$ & 52 & 11 & 20 & 79.52 & 2.39 & Yes & 59 & 1 & 8 & 91.67 & 2.75 & Yes & 6 & 7 & 4 & 70.59 & 2.12 & Maybe & 83.53 & Yes & $* 29.02$ \\
\hline $6 / 5$ & $\begin{array}{l}\text { A plan to increase the number of facilities } \\
\text { for sports tourism. }\end{array}$ & 59 & 17 & 7 & 87.55 & 2.63 & Yes & 63 & 3 & 2 & 96.57 & 2.90 & Yes & 8 & 5 & 4 & 74.51 & 2.24 & Maybe & 89.88 & Yes & $* 21.22$ \\
\hline $6 \backslash 6$ & $\begin{array}{l}\text { Providing the financial and human } \\
\text { capabilities required to stimulate sport } \\
\text { tourism. }\end{array}$ & 61 & 15 & 7 & $\mathbf{8 8 . 3 5}$ & 2.65 & Yes & 55 & 8 & 5 & 91.18 & 2.74 & Yes & 15 & 2 & $\mathbf{0}$ & 96.08 & 2.88 & Yes & 90.28 & Yes & 3.05 \\
\hline $6 / 7$ & $\begin{array}{l}\text { Providing specialists in the field of sports } \\
\text { tourism. }\end{array}$ & 66 & 5 & 12 & $\mathbf{8 8 . 3 5}$ & 2.65 & Yes & 64 & 2 & 2 & 97.06 & 2.91 & Yes & 13 & 4 & $\mathbf{0}$ & 92.16 & 2.76 & Yes & 92.26 & Yes & $* 17.50$ \\
\hline $6 / 8$ & $\begin{array}{l}\text { Providing media services to cover } \\
\text { international sporting competitions to } \\
\text { attract tourists. }\end{array}$ & 70 & 11 & 2 & 93.98 & 2.82 & Yes & 67 & 1 & 0 & 99.51 & 2.99 & Yes & 17 & 0 & $\mathbf{0}$ & 100.00 & 3.00 & Yes & 96.83 & Yes & *11.63 \\
\hline 7 & $\begin{array}{l}\text { There is an intent by the Ministry of } \\
\text { Youth and Sports to establish sports } \\
\text { facilities capable of hosting major } \\
\text { sporting events in Luxor. }\end{array}$ & 83 & 0 & $\mathbf{0}$ & 100.00 & 3.00 & Yes & 68 & 0 & 0 & 100.00 & 3.00 & Yes & 17 & 0 & $\mathbf{0}$ & 100.00 & 3.00 & Yes & 100 & Yes & 0.01 \\
\hline
\end{tabular}

Chi value $(0.05)=5.99$ weighted avg: No $(1: 1.67)$, maybe $(1.68: 2.33)$, yes $(2.34: 3)$ 
Continued table (9)

\begin{tabular}{|c|c|c|c|c|c|c|c|c|c|c|c|c|c|c|c|c|c|c|c|c|c|c|}
\hline \multirow{2}{*}{$\mathbf{N}$} & \multirow{2}{*}{ Statements } & \multicolumn{6}{|c|}{$\begin{array}{c}\text { Officials and workers of the Ministry of } \\
\text { Youth and Sports = 83 }\end{array}$} & \multicolumn{6}{|c|}{$\begin{array}{c}\text { Officials and workers of the Ministry of } \\
\text { Tourism }=68\end{array}$} & \multicolumn{6}{|c|}{ Academic professors = 17} & \multicolumn{3}{|c|}{ Research group } \\
\hline & & Yes & Maybe & No & W.R. & Avg. & Dir. & Yes & Maybe & No & W.R. & Avg. & Dir. & Yes & Maybe & No & W.R. & Avg. & Dir. & W.R. & Dir. & Chi \\
\hline 8 & $\begin{array}{l}\text { The Ministry of Youth and Sports } \\
\text { is going to build a stadium in Luxor } \\
\text { Governorate. }\end{array}$ & 75 & 8 & $\mathbf{0}$ & 96.79 & 2.90 & Yes & 65 & 2 & 1 & 98.04 & 2.94 & Yes & 17 & $\mathbf{0}$ & $\mathbf{0}$ & 100.00 & 3.00 & Yes & 97.62 & Yes & 5.61 \\
\hline 9 & $\begin{array}{l}\text { The entities responsible for the } \\
\text { success of sports tourism are: }\end{array}$ & & & & & & & & & & & & & & & & & & & & & \\
\hline $9 / 1$ & Ministry of Youth and Sports. & 83 & $\mathbf{0}$ & $\mathbf{0}$ & 100.00 & 3.00 & Yes & 68 & $\mathbf{0}$ & $\mathbf{0}$ & 100.00 & 3.00 & Yes & 17 & $\mathbf{0}$ & $\mathbf{0}$ & 100.00 & 3.00 & Yes & 100 & Yes & 0.01 \\
\hline $9 / 2$ & Ministry of Tourism. & 83 & $\mathbf{0}$ & $\mathbf{0}$ & 100.00 & 3.00 & Yes & 68 & $\mathbf{0}$ & $\mathbf{0}$ & 100.00 & 3.00 & Yes & 17 & $\mathbf{0}$ & $\mathbf{0}$ & 100.00 & 3.00 & Yes & 100 & Yes & 0.01 \\
\hline $9 / 3$ & Tourism Promotion Authority. & 83 & $\mathbf{0}$ & $\mathbf{0}$ & 100.00 & 3.00 & Yes & 68 & $\mathbf{0}$ & $\mathbf{0}$ & 100.00 & 3.00 & Yes & 17 & $\mathbf{0}$ & $\mathbf{0}$ & 100.00 & 3.00 & Yes & 100 & Yes & 0.01 \\
\hline $9 / 4$ & Ministry of Information. & 83 & $\mathbf{0}$ & $\mathbf{0}$ & 100.00 & 3.00 & Yes & 68 & $\mathbf{0}$ & $\mathbf{0}$ & 100.00 & 3.00 & Yes & 17 & $\mathbf{0}$ & $\mathbf{0}$ & 100.00 & 3.00 & Yes & 100 & Yes & 0.01 \\
\hline 10 & $\begin{array}{l}\text { There is a sport tourism program } \\
\text { established by the Ministry of } \\
\text { Tourism. }\end{array}$ & 83 & $\mathbf{0}$ & $\mathbf{0}$ & 100.00 & 3.00 & Yes & 68 & $\mathbf{0}$ & $\mathbf{0}$ & 100.00 & 3.00 & Yes & 17 & 0 & 0 & 100.00 & 3.00 & Yes & 100 & Yes & 0.01 \\
\hline 11 & $\begin{array}{l}\text { A budget is set to support and } \\
\text { stimulate sport tourism. }\end{array}$ & 66 & 12 & 5 & 91.16 & 2.73 & Yes & 59 & 4 & 5 & 93.14 & 2.79 & Yes & 10 & 5 & 2 & 82.35 & 2.47 & Yes & 91.07 & Yes & $* 8.52$ \\
\hline 12 & $\begin{array}{l}\text { The Ministry of Tourism requires } \\
\text { tourism companies to provide flyers } \\
\text { to motivate tourists to practice } \\
\text { sporting activities in them. }\end{array}$ & 0 & 5 & 78 & 35.34 & 1.06 & No & 19 & 5 & 44 & 54.41 & 1.63 & No & 0 & 0 & 17 & 33.33 & 1.00 & No & 42.86 & No & $* 33.73$ \\
\hline 13 & $\begin{array}{l}\text { There are legislations for sports } \\
\text { tourism. }\end{array}$ & 15 & 3 & 65 & 46.59 & 1.40 & No & 19 & 10 & 39 & 56.86 & 1.71 & Maybe & 1 & 5 & 11 & 47.06 & 1.41 & No & 50.79 & No & *16.68 \\
\hline
\end{tabular}


It is clear from Table No. (9) there are statistically significant differences at the level (0.05) between responses of the research categories to $(5,6 / 7,6 / 8,11)$ where opinions were in the yes direction with value of Chi ranged (8.52*: 17.50.(*

Ashraf Samir Al-Midani (2005), confirms that specialists who are able to work in the field of sports tourism are not available in Egypt, and there are deficiencies in the performance of media in the success of Egyptian sports tourism. (5: 17(

The researcher believes that it is necessary to provide specialists with awareness and knowledge of the concept of sport tourism and able to make various decisions in sporting events to maximize the return and stimulate sports tourism.

While the responses were not statistically significant among the research categories about the statements $(6 / 6,7,8,9 / 1,9 / 2,9 / 3,9 / 4,10)$ where the responses were in yes direction with value of Chi between (0.01: 5.61).

Muhammad Munir Hijab (2002) states that sports tourism progress requires the provision of capabilities and synergy of effective media power in order to attract the masses to practice tourism through sports. (26:11)

The researcher believes that it is the conscious leaders' responsibility to bring the world championships to Luxor to develop sport tourism.

The results of the table showed statistically significant differences between responses in the Ministry of Tourism, and academic professors around statement (6/1) where their responses came in yes direction, while for the Ministry of Youth and Sports were directed to maybe with Chi $(22.49 *)$.

The study of Buckley, M. Ferd (2010) (8) indicates tourism in all its forms has an effective role in supporting the country's economies and improving the individual's income, and being the most appropriate modern solution that can be used when economic crises occur.

The results of Nadia Lotfy Abdel Fattah (2008) (28) study, which reached the importance of organizing sporting events and its role in providing many job opportunities and developing services in the country.

The researcher agrees with the officials of Ministry of Youth and Sports that there may be cooperation between it and the Ministry of Tourism, but it is not sufficient to revitalize the concept of sport tourism.

Also there are statistically significant differences between responses in Ministry of Youth and Sports and in Ministry of Tourism around statements $(6 / 2,6 / 3,6 / 4,6 / 5)$ where their responses were in yes direction while for academics in maybe direction with Chi value $(16.81 *: 31.24 *)$.

Emama Samir Muhammad (2000) (10), confirms there are sports facilities in Egypt suitable for marketing of sports tourism, but they are few and not sufficient, and recommended the identification of tourist attractions in Egypt.

The researcher believes tourism and sports are powerful tools for development. A clear methodology must be used to imporve sports tourism to meet requirements and expectations of tourists internally and externally.

Also the table showed there are no statistically significant differences between the responses in the Ministry of Youth and Sports and academics around statement (13), where their responses came in no direction, while for the Ministry of Tourism were in maybe direction with Chi $(16.68 *)$.

Sally Said Abdo (2016) (35) study confirms there is no special legislation for sport tourism within the fields of investment and development, and the lack of courses for workers on sports tourism to stimulate tourism pattern.

In the researcher's opinion, it is necessary to develop legislation and encouraging sports tourism, such as issuing entry visas for it, or contracting with one of the world sports figures as an ambassador for Egyptian sports to develop sports tourism. 
Table (10) results of iterations, weighting ratio, average value and prevailing direction, and the value of Chi to indicate the differences between (research categories) and (research group) to respond to the third axis

\begin{tabular}{|c|c|c|c|c|c|c|c|c|c|c|c|c|c|c|c|c|c|c|c|c|c|c|}
\hline \multirow{2}{*}{$\mathbf{N}$} & \multirow{2}{*}{ Statement } & \multicolumn{6}{|c|}{ Officials and workers of the Ministry of Youth and Sports = 83} & \multicolumn{6}{|c|}{ Officials and workers of the Ministry of Tourism $=68$} & \multicolumn{6}{|c|}{ Academic professors $=17$} & \multicolumn{3}{|c|}{ Research group } \\
\hline & & Yes & Maybe & No & W.R. & Avg. & Dir. & Yes & Maybe & No & W.R. & Avg. & Dir. & Yes & Maybe & No & W.R. & Avg. & Dir. & W.R. & Dir. & Chi \\
\hline 14 & $\begin{array}{l}\text { The importance of establishing a sports stadium in Luxor } \\
\text { Governorate is: }\end{array}$ & & & & & & & & & & & & & & & & & & & & & \\
\hline $14 / 1$ & \begin{tabular}{|l} 
Eliminating unemployment. \\
\end{tabular} & 83 & $\mathbf{0}$ & $\mathbf{0}$ & 100.00 & 3.00 & Yes & 68 & $\mathbf{0}$ & $\mathbf{0}$ & 100.00 & 3.00 & Yes & $\mathbf{1 7}$ & $\mathbf{0}$ & $\mathbf{0}$ & 100.00 & 3.00 & Yes & 100 & Yes & 0.01 \\
\hline $14 / 2$ & \begin{tabular}{|l} 
Reviving national income and profitability. \\
\end{tabular} & $\mathbf{8 3}$ & $\mathbf{0}$ & $\mathbf{0}$ & 100.00 & 3.00 & Yes & 68 & $\mathbf{0}$ & $\mathbf{0}$ & 100.00 & $\mathbf{3 . 0 0}$ & Yes & 17 & $\mathbf{0}$ & $\mathbf{0}$ & 100.00 & 3.00 & Yes & 100 & Yes & 0.01 \\
\hline $14 / 3$ & $\begin{array}{l}\text { Higher per capita income to increase national income in } \\
\text { the Arab Republic of Egypt. }\end{array}$ & 83 & $\mathbf{0}$ & $\mathbf{0}$ & 100.00 & 3.00 & Yes & 68 & $\mathbf{0}$ & $\mathbf{0}$ & 100.00 & 3.00 & Yes & 17 & $\mathbf{0}$ & $\mathbf{0}$ & 100.00 & 3.00 & Yes & 100 & Yes & 0.01 \\
\hline $14 / 4$ & Increasing the foreign currency. & 83 & $\mathbf{0}$ & $\mathbf{0}$ & 100.00 & 3.00 & Yes & 68 & $\mathbf{0}$ & $\mathbf{0}$ & 100.00 & $\mathbf{3 . 0 0}$ & Yes & 17 & $\mathbf{0}$ & $\mathbf{0}$ & 100.00 & 3.00 & Yes & 100 & Yes & 0.01 \\
\hline $14 / 5$ & $\begin{array}{l}\text { Motivate the movement of domestic and foreign tourism } \\
\text { in Egypt. }\end{array}$ & 83 & $\mathbf{0}$ & $\mathbf{0}$ & 100.00 & 3.00 & Yes & 68 & $\mathbf{0}$ & $\mathbf{0}$ & 100.00 & 3.00 & Yes & 17 & $\mathbf{0}$ & $\mathbf{0}$ & 100.00 & 3.00 & Yes & 100 & Yes & 0.01 \\
\hline $14 / 6$ & $\begin{array}{l}\text { Increase in the number of tourists as an audience } \\
\text { following sporting events. }\end{array}$ & 83 & $\mathbf{0}$ & $\mathbf{0}$ & 100.00 & 3.00 & Yes & 68 & $\mathbf{0}$ & $\mathbf{0}$ & 100.00 & 3.00 & Yes & 17 & $\mathbf{0}$ & $\mathbf{0}$ & 100.00 & 3.00 & Yes & 100 & Yes & 0.01 \\
\hline $14 / 7$ & Attracting athletes and international teams. & 83 & $\mathbf{0}$ & $\mathbf{0}$ & 100.00 & 3.00 & Yes & 68 & $\mathbf{0}$ & $\mathbf{0}$ & 100.00 & $\mathbf{3 . 0 0}$ & Yes & 17 & $\mathbf{0}$ & $\mathbf{0}$ & 100.00 & 3.00 & Yes & 100 & Yes & 0.01 \\
\hline $14 / 8$ & $\begin{array}{l}\text { Raise Egypt's position and put it on the sportive tourist } \\
\text { map. }\end{array}$ & 83 & $\mathbf{0}$ & $\mathbf{0}$ & 100.00 & 3.00 & Yes & 68 & $\mathbf{0}$ & $\mathbf{0}$ & 100.00 & 3.00 & Yes & 17 & $\mathbf{0}$ & $\mathbf{0}$ & 100.00 & 3.00 & Yes & 100 & Yes & 0.01 \\
\hline $14 / 9$ & $\begin{array}{l}\text { The ability to organize sporting events, which is one of } \\
\text { the attractions of tourism. }\end{array}$ & 83 & $\mathbf{0}$ & $\mathbf{0}$ & 100.00 & 3.00 & Yes & 68 & $\mathbf{0}$ & $\mathbf{0}$ & 100.00 & 3.00 & Yes & 17 & 0 & $\mathbf{0}$ & 100.00 & 3.00 & Yes & 100 & Yes & 0.01 \\
\hline $14 / 10$ & $\begin{array}{l}\text { Set up friendly matches to allow for increased } \\
\text { opportunities to meet with different teams. }\end{array}$ & 83 & 0 & 0 & 100.00 & 3.00 & Yes & 68 & 0 & 0 & 100.00 & 3.00 & Yes & 17 & 0 & 0 & 100.00 & 3.00 & Yes & 100 & Yes & 0.01 \\
\hline $14 / 11$ & It may raise the profile of some sports, like: & & & & & & & & & & & & & & & & & & & & & \\
\hline 14/11/1 & Luxor clubs escalation to the Premier League. & 83 & $\mathbf{0}$ & $\mathbf{0}$ & 100.00 & 3.00 & Yes & 55 & 6 & 7 & 90.20 & 2.71 & Yes & 17 & $\mathbf{0}$ & $\mathbf{0}$ & 100.00 & 3.00 & Yes & 96.03 & Yes & $* 20.72$ \\
\hline $14 / 11 / 2$ & Athletics activities (pitch and track). & 66 & 13 & 4 & 91.57 & 2.75 & Yes & 57 & 5 & 6 & 91.67 & 2.75 & Yes & 14 & 2 & $\mathbf{1}$ & 92.16 & 2.76 & Yes & 91.67 & Yes & 3.18 \\
\hline $14 / 11 / 3$ & \begin{tabular}{|l|} 
Rugby tournaments \\
\end{tabular} & $\mathbf{5 0}$ & 16 & 17 & 79.92 & 2.40 & Yes & 51 & 11 & 6 & 88.73 & 2.66 & Yes & 14 & 1 & 2 & 90.20 & 2.71 & Yes & 84.52 & Yes & $* 6.80$ \\
\hline $14 / 12$ & $\begin{array}{l}\text { Intercultural exchange between the audience during } \\
\text { sporting events. }\end{array}$ & 52 & 9 & 22 & 78.71 & 2.36 & Yes & 49 & 8 & 11 & 85.29 & 2.56 & Yes & 12 & 2 & 3 & 84.31 & 2.53 & Yes & 81.94 & Yes & 2.54 \\
\hline $14 / 13$ & $\begin{array}{l}\text { Build understanding between teams in championships } \\
\text { and sporting events. }\end{array}$ & 60 & 13 & 10 & 86.75 & 2.60 & Yes & 55 & 6 & 7 & 90.20 & 2.71 & Yes & 14 & 0 & 3 & 88.24 & 2.65 & Yes & 88.29 & Yes & 4.74 \\
\hline $14 \backslash 14$ & Making conferences to promote sport tourism. & 58 & 12 & 13 & 84.74 & 2.54 & Yes & 58 & 4 & 6 & 92.16 & 2.76 & Yes & 15 & 1 & 1 & 94.12 & 2.82 & Yes & 88.69 & Yes & *6.49 \\
\hline $14 / 15$ & Optimizing the available economic resources. & 49 & 15 & 19 & 78.71 & 2.36 & Yes & 68 & $\mathbf{0}$ & $\mathbf{0}$ & 100.00 & $\mathbf{3 . 0 0}$ & Yes & 16 & $\mathbf{0}$ & 1 & 96.08 & 2.88 & Yes & 89.09 & Yes & $* 40.85$ \\
\hline $14 / 16$ & $\begin{array}{l}\text { Building a sports entity raises the country's standing in } \\
\text { the global sports community. }\end{array}$ & 83 & $\mathbf{0}$ & $\mathbf{0}$ & 100.00 & 3.00 & Yes & 68 & $\mathbf{0}$ & $\mathbf{0}$ & 100.00 & $\mathbf{3 . 0 0}$ & Yes & 16 & 1 & $\mathbf{0}$ & $\mathbf{9 8 . 0 4}$ & 2.94 & Yes & $\mathbf{9 9 . 8 0}$ & Yes & $* 8.94$ \\
\hline $14 / 17$ & $\begin{array}{l}\text { Optimum utilization of unexploited lands in a manner } \\
\text { that eliminates unemployment. }\end{array}$ & 83 & 0 & $\mathbf{0}$ & 100.00 & 3.00 & Yes & 68 & $\mathbf{0}$ & $\mathbf{0}$ & 100.00 & $\mathbf{3 . 0 0}$ & Yes & 17 & $\mathbf{0}$ & $\mathbf{0}$ & 100.00 & 3.00 & Yes & 100 & Yes & 0.00 \\
\hline $14 / 18$ & $\begin{array}{l}\text { Raising economic value of the resources available to } \\
\text { which exploitation didn't extend. }\end{array}$ & 83 & $\mathbf{0}$ & $\mathbf{0}$ & 100.00 & 3.00 & Yes & 57 & 5 & 6 & 91.67 & 2.75 & Yes & 17 & $\mathbf{0}$ & $\mathbf{0}$ & 100.00 & 3.00 & Yes & 96.63 & Yes & $* 17.31$ \\
\hline $14 / 19$ & Satisfy the needs of citizens who follow sports events. & 83 & $\mathbf{0}$ & $\mathbf{0}$ & 100.00 & 3.00 & Yes & 55 & 5 & $\mathbf{8}$ & 89.71 & 2.69 & Yes & 17 & $\mathbf{0}$ & $\mathbf{0}$ & 100.00 & 3.00 & Yes & 95.83 & Yes & $* \mathbf{2 0 . 7 2}$ \\
\hline $14 / 20$ & $\begin{array}{l}\text { Attracting sports sponsors and investing in tournaments } \\
\text { that take place in the stadium. }\end{array}$ & 83 & $\mathbf{0}$ & $\mathbf{0}$ & 100.00 & 3.00 & Yes & 68 & 0 & $\mathbf{0}$ & 100.00 & $\mathbf{3 . 0 0}$ & Yes & 17 & $\mathbf{0}$ & $\mathbf{0}$ & 100.00 & 3.00 & Yes & 100 & Yes & 0.01 \\
\hline $14 / 21$ & $\begin{array}{l}\text { Opening a new window for sport to revitalize it for } \\
\text { tourism. }\end{array}$ & 83 & 0 & $\mathbf{0}$ & 100.00 & 3.00 & Yes & 60 & 4 & 4 & 94.12 & 2.82 & Yes & 17 & 0 & $\mathbf{0}$ & 100.00 & 3.00 & Yes & 97.62 & Yes & *12.35 \\
\hline
\end{tabular}

Chi value $(0.05)=5.99$ weighted avg: No $(1: 1.67)$, maybe (1.68: 2.33), yes (2.34: 3$)$ 
Continued table (10)

\begin{tabular}{|c|c|c|c|c|c|c|c|c|c|c|c|c|c|c|c|c|c|c|c|c|c|c|}
\hline \multirow[b]{2}{*}{$\mathbf{N}$} & \multirow[b]{2}{*}{ Statements } & \multicolumn{6}{|c|}{ Officials and workers of the Ministry of Youth and Sports = 83} & \multicolumn{6}{|c|}{ Officials and workers of the Ministry of Tourism $=68$} & \multicolumn{6}{|c|}{ Academic professors $=17$} & \multicolumn{3}{|c|}{ Research group } \\
\hline & & Yes & Maybe & No & W.R. & Avg. & Dir. & Yes & Maybe & No & W.R. & Avg. & Dir. & Yes & Maybe & No & W.R. & Avg. & Dir. & W.R. & Dir. & Chi. \\
\hline 15 & $\begin{array}{l}\text { Public that benefits from the construction of } \\
\text { a stadium in Luxor includes the following: }\end{array}$ & & & & & & & & & & & & & & & & & & & & & \\
\hline $15 / 1$ & Foreign tourists following sports. & 83 & $\mathbf{0}$ & $\mathbf{0}$ & $\mathbf{1 0 0 . 0 0}$ & 3.00 & Yes & 68 & $\mathbf{0}$ & $\mathbf{0}$ & 100.00 & 3.00 & Yes & 17 & $\mathbf{0}$ & $\mathbf{0}$ & 100.00 & 3.00 & Yes & 100 & Yes & 0.01 \\
\hline $15 / 2$ & Arab tourists following sports. & 83 & $\mathbf{0}$ & $\mathbf{0}$ & 100.00 & 3.00 & Yes & 68 & $\mathbf{0}$ & $\mathbf{0}$ & 100.00 & 3.00 & Yes & 17 & $\mathbf{0}$ & $\mathbf{0}$ & 100.00 & 3.00 & Yes & 100 & Yes & 0.01 \\
\hline $15 / 3$ & Athletes participating in championship. & 83 & $\mathbf{0}$ & $\mathbf{0}$ & 100.00 & 3.00 & Yes & 68 & $\mathbf{0}$ & $\mathbf{0}$ & 100.00 & 3.00 & Yes & 17 & $\mathbf{0}$ & $\mathbf{0}$ & 100.00 & 3.00 & Yes & 100 & Yes & 0.01 \\
\hline $15 / 4$ & Media professionals following sport events. & 56 & 10 & 17 & 82.33 & 2.47 & Yes & 57 & 4 & 7 & 91.18 & 2.74 & Yes & 17 & $\mathbf{0}$ & $\mathbf{0}$ & 100.00 & 3.00 & Yes & 87.70 & Yes & $* 11.24$ \\
\hline $15 / 5$ & Coaches and administrators. & 57 & 14 & 12 & 84.74 & 2.54 & Yes & 55 & 7 & 6 & 90.69 & 2.72 & Yes & 17 & $\mathbf{0}$ & $\mathbf{0}$ & 100.00 & 3.00 & Yes & 88.69 & Yes & $* 8.84$ \\
\hline $15 / 6$ & People interested in sports. & 52 & 11 & 20 & 79.52 & 2.39 & Yes & 52 & 8 & 8 & 88.24 & 2.65 & Yes & 17 & $\mathbf{0}$ & $\mathbf{0}$ & 100.00 & 3.00 & Yes & 85.12 & Yes & $* 11.82$ \\
\hline $15 / 7$ & Owners of tourist facilities. & 33 & 18 & 32 & 67.07 & 2.01 & Maybe & 50 & 10 & 8 & 87.25 & 2.62 & Yes & 17 & $\mathbf{0}$ & $\mathbf{0}$ & 100.00 & 3.00 & Yes & 78.57 & Yes & $* 32.38$ \\
\hline $15 / 8$ & Hotel owners. & 83 & $\mathbf{0}$ & $\mathbf{0}$ & 100.00 & 3.00 & Yes & 53 & 7 & 8 & 88.73 & 2.66 & Yes & 17 & $\mathbf{0}$ & $\mathbf{0}$ & 100.00 & 3.00 & Yes & 95.44 & Yes & $* 24.22$ \\
\hline $15 / 9$ & Shop owners. & 80 & 3 & $\begin{array}{lll}\mathbf{0} & & \\
\end{array}$ & 98.80 & 2.96 & Yes & 56 & 7 & 5 & 91.67 & 2.75 & Yes & 17 & $\mathbf{0}$ & $\mathbf{0}$ & 100.00 & 3.00 & Yes & 96.03 & Yes & $* 12.25$ \\
\hline $15 / 10$ & Restaurants and cafes. & 83 & $\mathbf{0}$ & $\mathbf{0}$ & 100.00 & 3.00 & Yes & 57 & 5 & 6 & 91.67 & 2.75 & Yes & 17 & $\mathbf{0}$ & $\mathbf{0}$ & 100.00 & 3.00 & Yes & 96.63 & Yes & $* 17.31$ \\
\hline 16 & The country benefits fromsports tourism by: & & & & & & & & & & & & & & & & & & & & & \\
\hline $16 / 1$ & $\begin{array}{l}\text { The financial and economic returns resulting } \\
\text { from hosting the event or championship. }\end{array}$ & 83 & $\mathbf{0}$ & $\mathbf{0}$ & 100.00 & 3.00 & Yes & 67 & 1 & $\mathbf{0}$ & 99.51 & 2.99 & Yes & 17 & $\mathbf{0}$ & $\mathbf{0}$ & 100.00 & 3.00 & Yes & 99.80 & Yes & 1.49 \\
\hline $16 / 2$ & $\begin{array}{l}\text { Participation in international sporting events } \\
\text { and championships. }\end{array}$ & 83 & $\mathbf{0}$ & $\mathbf{0}$ & 100.00 & 3.00 & Yes & 68 & $\mathbf{0}$ & $\mathbf{0}$ & 100.00 & 3.00 & Yes & 17 & $\mathbf{0}$ & $\mathbf{0}$ & 100.00 & 3.00 & Yes & 100 & Yes & 0.01 \\
\hline $16 / 3$ & Promoting sports tourism in Luxor. & 83 & $\mathbf{0}$ & $\mathbf{0}$ & 100.00 & 3.00 & Yes & 68 & $\mathbf{0}$ & $\mathbf{0}$ & 100.00 & 3.00 & Yes & 17 & $\mathbf{0}$ & $\mathbf{0}$ & 100.00 & 3.00 & Yes & 100 & Yes & 0.01 \\
\hline $16 / 4$ & Sports meeting with global teams. & 83 & $\mathbf{0}$ & $\mathbf{0}$ & 100.00 & 3.00 & Yes & 53 & 7 & 8 & 88.73 & 2.66 & Yes & 17 & $\mathbf{0}$ & $\mathbf{0}$ & 100.00 & 3.00 & Yes & 95.44 & Yes & $* 24.22$ \\
\hline $16 / 5$ & Increased demand for: & & & & & & & & & & & & & & & & & & & & & \\
\hline 16/5/1 & Airports and tourist services & 83 & $\mathbf{0}$ & $\mathbf{0}$ & 100.00 & 3.00 & Yes & 51 & 7 & $\mathbf{1 0}$ & 86.76 & 2.60 & Yes & 17 & $\mathbf{0}$ & $\mathbf{0}$ & 100.00 & 3.00 & Yes & 94.64 & Yes & $* 27.81$ \\
\hline $16 / 5 / 2$ & Ports. & 83 & $\mathbf{0}$ & $\mathbf{0}$ & 100.00 & 3.00 & Yes & 50 & 11 & 7 & 87.75 & 2.63 & Yes & 17 & $\mathbf{0}$ & $\mathbf{0}$ & 100.00 & 3.00 & Yes & 95.04 & Yes & $* 29.64$ \\
\hline $16 / 5 / 3$ & Domestic transportation. & 80 & 3 & $\begin{array}{lll}\mathbf{0} & & \\
\end{array}$ & 98.80 & 2.96 & Yes & 49 & 8 & 11 & 85.29 & 2.56 & Yes & 17 & $\mathbf{0}$ & $\mathbf{0}$ & 100.00 & 3.00 & Yes & 93.45 & Yes & $* 24.12$ \\
\hline $16 / 5 / 4$ & Tourist attractions and sports facilities. & 83 & $\mathbf{0}$ & $\mathbf{0}$ & 100.00 & 3.00 & Yes & 68 & $\mathbf{0}$ & $\mathbf{0}$ & 100.00 & 3.00 & Yes & 17 & $\mathbf{0}$ & $\mathbf{0}$ & 100.00 & 3.00 & Yes & 100 & Yes & 0.01 \\
\hline $16 / 5 / 5$ & $\begin{array}{l}\text { Hotels in the governorate refresh } \\
\text { occupations in the off-season. }\end{array}$ & 83 & $\mathbf{0}$ & $\mathbf{0}$ & 100.00 & 3.00 & Yes & 68 & $\mathbf{0}$ & $\mathbf{0}$ & 100.00 & 3.00 & Yes & 17 & $\mathbf{0}$ & $\mathbf{0}$ & 100.00 & 3.00 & Yes & 100 & Yes & 0.01 \\
\hline
\end{tabular}

Chi value (0.05) $=5.99$ weighted avg: No (1: 1.67), maybe (1.68: 2.33), yes (2.34: 3) 
It is clear from Table (10) that there are statistically significant differences at the level (0.05) between responses of the research categories to statements $(14 / 1,14 / 2,14 / 3$, $14 / 4,14 / 5,14 / 6,14 / 7,14 / 8,14 / 9,14 / 11 / 2,14 / 12,14 / 13,14 / 14,14 / 17,14 / 20,15 / 1$, $15 / 2,16 / 1,15 / 3,16 / 2,16 / 3,16 / 5 / 4,16 / 5 / 5)$ where the opinions were in yes direction with Chi between (0.00: 4.74).

Ahmed Mahmoud Mokabla (2007) indicates that tourism is of great importance as it contributes to supporting the local and global economy, works to attract capital and hard currencies, and helps in the employment of a large number of manpower and eliminate unemployment. (3: 26-28)

The researcher believes that sport tourism contributes to increasing national income and raising the standard of living. Sports events and facilities are one of the ways in which the goals of sport tourism can be achieved.

Also responses were statistically significant among the research categories around statements $(14 / 11 / 1,14 / 11 / 3,14 / 14,14 / 15,14 / 16,14 / 18,14 / 19,14 / 21,15 / 4,15 / 5$, $15 / 6,15 / 8,15 / 9,15 / 10,16 / 4,16 / 5 / 1,16 / 5 / 2,16 / 5 / 3)$.

Mohamed Mahmoud Dahiba (2007) and the results of Buckley, M. Ferd (2010) (8) confirm that tourism is one of the world's major industries today that it even exceeds agricultural and industrial growth rates. (25:23)

The researcher believes there are no sports facilities to serve sports tourism, and the current doesn't meet the needs of tournaments and sporting events.

There are also statistically significant differences between responses in the Ministry of Tourism, and academics around statement (15/7) where their responses came in yes direction with the opinions in the Ministry of Youth and Sports were directed to maybe with Chi value $(32.38 *)$.

In this regard, Ibrahim Mahmoud Abdel-Maqsoud and Hassan Ahmed Al-Shafi'i (2004) indicate that the beneficiaries of sport tourism are not one party or limited to specific parties, as the country benefits from all its bodies and individuals from sports tourism and benefits various entities. (20:15)

The researcher believes that sports tourism serves all parties, we must work to spread awareness of the importance of sports tourism through which to increase revenues from foreign exchange and create new job opportunities. 
Table (11) results of iterations, weighting ratio, average value and prevailing direction, and the value of Chi to indicate the differences between (research categories) and (research group) to respond to the fourth axis

\begin{tabular}{|c|c|c|c|c|c|c|c|c|c|c|c|c|c|c|c|c|c|c|c|c|c|c|}
\hline \multirow{2}{*}{$\mathbf{N}$} & \multirow{2}{*}{ Statements } & \multicolumn{6}{|c|}{ Officials and workers of the Ministry of Youth and Sports = 83} & \multicolumn{6}{|c|}{ Officials and workers of the Ministry of Tourism $=68$} & \multicolumn{6}{|c|}{ Academic professors $=17$} & \multicolumn{3}{|c|}{ Research group } \\
\hline & & Yes & Maybe & No & W.R. & Avg. & Dir. & Yes & Maybe & No & W.R. & Avg. & Dir. & Yes & Maybe & No & W.R. & Avg. & Dir. & W.R. & Dir. & Chi \\
\hline 17 & $\begin{array}{l}\text { The Ministry of Youth and Sports has a budget for a } \\
\text { sports stadium in Luxor Governorate, which is } \\
\text { sufficient for: }\end{array}$ & & & & & & & & & & & & & & & & & & & & & \\
\hline $17 / 1$ & Establish the stadium infrastructure. & 49 & 19 & 15 & 80.32 & 2.41 & Yes & $\mathbf{5 0}$ & 7 & 11 & $\mathbf{8 5 . 7 8}$ & 2.57 & Yes & 17 & $\mathbf{0}$ & $\mathbf{0}$ & 100.00 & 3.00 & Yes & 84.52 & Yes & $\mathbf{1 3 . 5 4}$ \\
\hline $17 / 2$ & Attachments attached to the stadium. & 47 & 17 & 19 & 77.91 & 2.34 & Maybe & 40 & 14 & 14 & 79.41 & 2.38 & Yes & 16 & 1 & $\mathbf{0}$ & 98.04 & 2.94 & Yes & 80.56 & Yes & 8.89 \\
\hline $17 / 3$ & Furniture, equipment, tools and appliances. & $\mathbf{5 0}$ & 10 & 23 & 77.51 & 2.33 & Maybe & 44 & 15 & 9 & $\mathbf{8 3 . 8 2}$ & 2.51 & Yes & 15 & 2 & $\mathbf{0}$ & 96.08 & 2.88 & Yes & 81.94 & Yes & $\mathbf{1 1 . 9 7}$ \\
\hline $17 / 4$ & Staff salaries. & 57 & 8 & 18 & 82.33 & 2.47 & Yes & 56 & 12 & $\mathbf{0}$ & 94.12 & 2.82 & Yes & 15 & $\mathbf{1}$ & $\mathbf{1}$ & 94.12 & $\mathbf{2 . 8 2}$ & Yes & 88.29 & Yes & 19.89 \\
\hline $17 / 5$ & $\begin{array}{l}\text { Advertising campaign about the stadium and its } \\
\text { activities. }\end{array}$ & 40 & 23 & 20 & $\mathbf{7 4 . 7 0}$ & 2.24 & Maybe & 51 & $\mathbf{0}$ & 17 & $\mathbf{8 3 . 3 3}$ & 2.50 & Yes & 16 & 1 & $\mathbf{0}$ & 98.04 & 2.94 & Yes & 80.56 & Yes & 32.17 \\
\hline $17 / 6$ & Website design. & 59 & 8 & 16 & 83.94 & 2.52 & Yes & 39 & 15 & 14 & 78.92 & 2.37 & Yes & 17 & $\mathbf{0}$ & $\mathbf{0}$ & 100.00 & 3.00 & Yes & 83.53 & Yes & 13.99 \\
\hline 18 & The human need required are: & & & & & & & & & & & & & & & & & & & & & \\
\hline $18 / 1$ & General Director. & 83 & $\mathbf{0}$ & $\mathbf{0}$ & 100.00 & $\mathbf{3 . 0 0}$ & Yes & 55 & 13 & $\mathbf{0}$ & 93.63 & 2.81 & Yes & 17 & $\mathbf{0}$ & $\mathbf{0}$ & 100.00 & 3.00 & Yes & 97.42 & Yes & 20.73 \\
\hline $18 / 2$ & $\begin{array}{l}\text { Executive Director. } \\
\end{array}$ & 83 & $\mathbf{0}$ & $\mathbf{0}$ & 100.00 & $\mathbf{3 . 0 0}$ & Yes & 56 & 6 & 6 & 91.18 & 2.74 & Yes & 17 & $\mathbf{0}$ & $\mathbf{0}$ & 100.00 & 3.00 & Yes & 96.43 & Yes & 19.00 \\
\hline $18 / 3$ & Financial manager. & 83 & $\mathbf{0}$ & $\mathbf{0}$ & 100.00 & $\mathbf{3 . 0 0}$ & Yes & 68 & $\mathbf{0}$ & $\mathbf{0}$ & 100.00 & 3.00 & Yes & 17 & $\mathbf{0}$ & $\mathbf{0}$ & 100.00 & 3.00 & Yes & 100 & Yes & 0.01 \\
\hline $18 / 4$ & Accountant. & 83 & $\mathbf{0}$ & $\mathbf{0}$ & 100.00 & $\mathbf{3 . 0 0}$ & Yes & 59 & 9 & $\mathbf{0}$ & 95.59 & 2.87 & Yes & 17 & $\mathbf{0}$ & $\mathbf{0}$ & 100.00 & 3.00 & Yes & 98.21 & Yes & 13.99 \\
\hline $18 / 5$ & Managing Director. & 83 & $\mathbf{0}$ & $\mathbf{0}$ & 100.00 & $\mathbf{3 . 0 0}$ & Yes & 55 & 6 & 7 & 90.20 & 2.71 & Yes & 17 & $\mathbf{0}$ & $\mathbf{0}$ & 100.00 & 3.00 & Yes & 96.03 & Yes & 20.72 \\
\hline $18 / 6$ & Public Relations Officer. & 65 & 5 & 13 & 87.55 & 2.63 & Yes & 49 & 10 & 9 & 86.27 & 2.59 & Yes & 17 & $\mathbf{0}$ & $\mathbf{0}$ & 100.00 & 3.00 & Yes & 88.29 & Yes & 8.85 \\
\hline $18 / 7$ & Marketer. & 66 & 4 & 13 & 87.95 & 2.64 & Yes & 51 & 9 & 8 & 87.75 & 2.63 & Yes & 17 & $\mathbf{0}$ & $\mathbf{0}$ & 100.00 & 3.00 & Yes & 89.09 & Yes & 8.77 \\
\hline $18 / 8$ & Marketing Specialist. & 80 & 3 & $\mathbf{0}$ & 98.80 & 2.96 & Yes & 56 & 5 & 7 & 90.69 & 2.72 & Yes & 15 & 2 & $\mathbf{0}$ & 96.08 & 2.88 & Yes & 95.24 & Yes & 13.07 \\
\hline $18 / 9$ & Lighting technician. & 68 & 2 & 13 & 88.76 & 2.66 & Yes & 53 & 5 & $\mathbf{1 0}$ & 87.75 & 2.63 & Yes & 14 & 3 & $\mathbf{0}$ & 94.12 & 2.82 & Yes & 88.89 & Yes & 8.58 \\
\hline $18 / 10$ & Sports Supervisor. & 73 & 5 & 5 & 93.98 & 2.82 & Yes & $\mathbf{5 0}$ & 11 & 7 & 87.75 & 2.63 & Yes & 15 & 2 & $\mathbf{0}$ & 96.08 & 2.88 & Yes & 91.67 & Yes & 6.95 \\
\hline 18/11 & Support services. & 80 & 2 & 1 & 98.39 & 2.95 & Yes & 68 & $\mathbf{0}$ & $\mathbf{0}$ & 100.00 & 3.00 & Yes & 17 & $\mathbf{0}$ & $\mathbf{0}$ & 100.00 & 3.00 & Yes & 99.21 & Yes & 3.13 \\
\hline $18 / 12$ & Electricity technician. & 81 & $\mathbf{1}$ & 1 & 98.80 & 2.96 & Yes & 51 & 9 & 8 & $\mathbf{8 7 . 7 5}$ & 2.63 & Yes & 16 & $\mathbf{1}$ & $\mathbf{0}$ & 98.04 & 2.94 & Yes & 94.25 & Yes & 19.31 \\
\hline $18 / 13$ & Electronics technician. & 80 & $\mathbf{0}$ & 3 & 97.59 & 2.93 & Yes & 54 & 14 & $\mathbf{0}$ & 93.14 & 2.79 & Yes & 17 & $\mathbf{0}$ & $\mathbf{0}$ & 100.00 & 3.00 & Yes & 96.03 & Yes & 25.07 \\
\hline $18 / 14$ & Maintenance technician for devices. & 77 & 3 & 3 & 96.39 & 2.89 & Yes & 68 & $\mathbf{0}$ & $\mathbf{0}$ & 100.00 & 3.00 & Yes & 15 & 2 & $\mathbf{0}$ & 96.08 & 2.88 & Yes & 97.82 & Yes & 9.92 \\
\hline $18 / 15$ & Agricultural engineer. & 71 & 3 & 9 & 91.57 & 2.75 & Yes & 55 & 5 & 8 & 89.71 & 2.69 & Yes & 17 & $\mathbf{0}$ & $\mathbf{0}$ & 100.00 & 3.00 & Yes & 91.67 & Yes & 4.53 \\
\hline $18 / 16$ & Agricultural workers. & 69 & 2 & 12 & 89.56 & 2.69 & Yes & 62 & 6 & $\mathbf{0}$ & 97.06 & 2.91 & Yes & 17 & $\mathbf{0}$ & $\mathbf{0}$ & 100.00 & 3.00 & Yes & 93.65 & Yes & $\mathbf{1 7 . 0 0}$ \\
\hline $18 / 17$ & Grass worker. & 69 & 7 & 7 & 91.57 & 2.75 & Yes & 63 & 3 & 2 & 96.57 & 2.90 & Yes & 16 & 1 & $\mathbf{0}$ & 98.04 & 2.94 & Yes & 94.25 & Yes & 4.52 \\
\hline $18 \backslash 18$ & Storekeeper. & 83 & $\mathbf{0}$ & $\mathbf{0}$ & 100.00 & $\mathbf{3 . 0 0}$ & Yes & 55 & 6 & 7 & 90.20 & 2.71 & Yes & 17 & $\mathbf{0}$ & $\mathbf{0}$ & 100.00 & 3.00 & Yes & 96.03 & Yes & 20.72 \\
\hline 19 & $\begin{array}{l}\text { From your point of view, the organizational structure } \\
\text { necessary to establish a sports stadium in Luxor } \\
\text { Governorate is: }\end{array}$ & & & & & & & & & & & & & & & & & & & & & \\
\hline 19/1 & $\begin{array}{l}\text { Financial Affairs Department. } \\
\end{array}$ & 83 & $\mathbf{0}$ & $\mathbf{0}$ & 100.00 & $\mathbf{3 . 0 0}$ & Yes & 68 & $\mathbf{0}$ & $\mathbf{0}$ & 100.00 & 3.00 & Yes & \begin{tabular}{|l|l}
17 \\
\end{tabular} & $\mathbf{0}$ & $\mathbf{0}$ & 100.00 & 3.00 & Yes & 100 & Yes & 0.01 \\
\hline $19 / 2$ & Department of Administrative Affairs . & 83 & $\mathbf{0}$ & $\mathbf{0}$ & 100.00 & $\mathbf{3 . 0 0}$ & Yes & 68 & $\mathbf{0}$ & $\mathbf{0}$ & 100.00 & 3.00 & Yes & 17 & $\mathbf{0}$ & $\mathbf{0}$ & 100.00 & 3.00 & Yes & 100 & Yes & 0.01 \\
\hline $19 / 3$ & Department of stadiums and activities. & 83 & $\mathbf{0}$ & $\mathbf{0}$ & 100.00 & $\mathbf{3 . 0 0}$ & Yes & 68 & $\mathbf{0}$ & $\mathbf{0}$ & 100.00 & 3.00 & Yes & 17 & $\mathbf{0}$ & $\mathbf{0}$ & 100.00 & 3.00 & Yes & 100 & Yes & 0.01 \\
\hline $19 / 4$ & Facilities and Construction Section. & 83 & $\mathbf{0}$ & $\mathbf{0}$ & 100.00 & $\mathbf{3 . 0 0}$ & Yes & 60 & 4 & 4 & 94.12 & 2.82 & Yes & \begin{tabular}{|l|}
17 \\
\end{tabular} & 0 & 0 & 100.00 & 3.00 & Yes & 97.62 & Yes & 12.35 \\
\hline
\end{tabular}

Chi value $(0.05)=5.99$ weighted avg: No $(1: 1.67)$, maybe $(1.68: 2.33)$, yes $(2.34: 3)$ 


\section{Continued table (11)}

\begin{tabular}{|c|c|c|c|c|c|c|c|c|c|c|c|c|c|c|c|c|c|c|c|c|c|c|}
\hline \multirow{2}{*}{$\mathbf{N}$} & \multirow{2}{*}{ Statements } & \multicolumn{6}{|c|}{ Officials and workers of the Ministry of Youth and Sports = 83} & \multicolumn{6}{|c|}{ Officials and workers of the Ministry of Tourism $=68$} & \multicolumn{6}{|c|}{ Academic professors $=17$} & \multicolumn{3}{|c|}{ Research group } \\
\hline & & Yes & Maybe & No & W.R. & Avg. & Dir. & Yes & Maybe & No & W.R. & Avg. & Dir. & Yes & Maybe & No & W.R. & Avg. & Dir. & W.R. & Dir. & Chi \\
\hline $19 / 5$ & $\begin{array}{l}\text { Public Relations, ceremonies and } \\
\text { celebrations official. }\end{array}$ & 83 & $\mathbf{0}$ & $\mathbf{0}$ & 100.00 & 3.00 & Yes & 52 & 12 & 4 & 90.20 & 2.71 & Yes & 17 & $\mathbf{0}$ & $\mathbf{0}$ & 100.00 & 3.00 & Yes & 96.03 & Yes & 26.00 \\
\hline $19 / 6$ & Agricultural Engineering Department. & 83 & $\mathbf{0}$ & $\mathbf{0}$ & 100.00 & 3.00 & Yes & 56 & 10 & 2 & 93.14 & 2.79 & Yes & 17 & $\mathbf{0}$ & $\mathbf{0}$ & 100.00 & 3.00 & Yes & 97.22 & Yes & 19.00 \\
\hline 19/7 & Electrical department . & $\mathbf{8 3}$ & $\mathbf{0}$ & $\mathbf{0}$ & 100.00 & 3.00 & Yes & 58 & 5 & 5 & 92.65 & 2.78 & Yes & 17 & $\mathbf{0}$ & $\mathbf{0}$ & 100.00 & 3.00 & Yes & 97.02 & Yes & $\mathbf{1 5 . 6 3}$ \\
\hline $19 / 8$ & Department of Technical Workshops. & 83 & $\mathbf{0}$ & $\mathbf{0}$ & 100.00 & 3.00 & Yes & 53 & 9 & 6 & 89.71 & 2.69 & Yes & 17 & $\mathbf{0}$ & $\mathbf{0}$ & 100.00 & 3.00 & Yes & 95.83 & Yes & 24.22 \\
\hline 20 & $\begin{array}{l}\text { The Ministry of Tourism, Youth and } \\
\text { Sports has an information database for: }\end{array}$ & & & & & & & & & & & & & & & & & & & & & \\
\hline 20/1 & $\begin{array}{l}\text { Legal stadiums suitable for holding local } \\
\text { and international competitions in Luxor. }\end{array}$ & $\mathbf{0}$ & $\mathbf{0}$ & 83 & 33.33 & 1.00 & No & 51 & 8 & 9 & 87.25 & 2.62 & Yes & 2 & $\mathbf{0}$ & 15 & 41.18 & 1.24 & No & 55.95 & Maybe & 126.72 \\
\hline 20/2 & $\begin{array}{l}\text { The names of the administrators who } \\
\text { have the ability to organize local and } \\
\text { international sports competitions. }\end{array}$ & 1 & 2 & 80 & 34.94 & 1.05 & No & 68 & $\mathbf{0}$ & $\mathbf{0}$ & 100.00 & 3.00 & Yes & 4 & 2 & 11 & 52.94 & 1.59 & No & 63.10 & Maybe & 158.09 \\
\hline $20 / 3$ & Sports that can be organized in Luxor. & $\mathbf{0}$ & 3 & 80 & 34.54 & 1.04 & No & 65 & 3 & $\mathbf{0}$ & 98.53 & 2.96 & Yes & 4 & 1 & 12 & 50.98 & 1.53 & No & 62.10 & Maybe & 149.04 \\
\hline $20 / 4$ & Tourist places and attractions in Luxor. & 78 & 5 & $\mathbf{0}$ & 97.99 & 2.94 & Yes & 57 & $\mathbf{0}$ & 11 & 89.22 & 2.68 & Yes & 17 & $\mathbf{0}$ & $\mathbf{0}$ & 100.00 & 3.00 & Yes & & & 21.91 \\
\hline
\end{tabular}


It is clear from Table (11) that there are statistically significant differences at the level (0.05) between responses of the research categories on $(17 / 1,17 / 4,17 / 6,18 / 1,18 / 2$, $18 / 4,18 / 5,18 / 6,18 / 7,18 / 8,18 / 9,18 / 10,18 / 13,18 / 12,18 / 14,18 / 16,18 / 18,19 / 4$, $19 / 5,19 / 6,19 / 7,19 / 8,20 / 4)$, where opinions came in yes direction, and Chi ranged (6.95*: 25.07.(*

Ahmed Nabil Kamel Al-Sheikh (2004) (4) emphasize the need to make optimal use of the available capabilities to achieve desired goals, to qualify and train those working in the field of sports tourism, and develop the available capabilities.

The study of Walaa Muhammad Ibrahim (2011) (36) also recommended the need for a specialized website on the Internet to receive complaints and suggestions, and to provide appropriate employment for sports activities in the tourism field.

The researcher believes that, despite the availability of some material and human capabilities sufficient to hold sporting competitions, whether at the local or international level, but she does not find the sponsoring hand and establishments through which it can be employed in sport tourism, which is considered one of the most important types of tourism.

While the responses were not statistically significant among the research categories about the statements $(18 / 3,18 / 11,19 / 1,19 / 2,19 / 3)$, where the responses were in the direction of yes and the value of Chi ranged between $(0.01: 3.13)$.

Salah Osman Youssef (2013) emphasizes that the most important elements in the organizational structure is the financial manager because of his effective role in managing financial affairs, accounts, revenues and expenses, preparing the estimated budget, following up the actual rate of exchange and preparing the final accounts of the institution. (33: 16)

The researcher believes that the financial manager is not considered the most important in the organizational structure. Without all the different members, the desired goals will not be achieved, so the organizational structure is the tool aimed at performing the work efficiently and effectively.

The table shows that there are statistically significant differences between the responses of the Ministry of Tourism, and the academic professors about the statements $(17 / 2,17 / 3,17 / 5)$ where the responses of the two groups came in yes direction while opinions of the Ministry of Youth and Sports were in maybe direction and the value of Chi $(8.89 *: 32.17 *)$.

Ahmed Nabil Kamel Al-Sheikh (2004) (4), Hamdino Omar Al-Sayed (2011) (16), and Farid Hassanein Farid (2017) confirmed that tourism advertising campaigns are considered one of the most important means to attract the largest number of tourists, making it a major component of improving the level of Egyptian tourism (11: 19)

The researcher noted that there are many advertising campaigns for Egypt in the Arab market to stimulate tourism in general, but on the contrary, no advertising campaigns on sports tourism in Egypt were available in any way, which would negatively affect sports tourism.

While the results of the table showed that there are statistically significant differences between the responses of the Ministry of Youth and Sports and the category of academics about $(20 / 1,20 / 2,20 / 3)$ where the responses of the two groups came in no direction while the opinions of the Ministry of Tourism were in yes direction and value of Chi $(126.72 *$ : $158.09 *)$.

Hammad Karam El-Kabee(2012)(14) (, Haitham Bahaa El-Din Hassan (2018) also indicates the importance of databases because they work to provide information to business owners at the utmost speed, and through processing them appropriate 
decisions are taken, in addition to that it is necessary to create records for all administrators that can be employed in various tasks. $(18: 91)$

The researcher believes that the database is of great importance to highlight many points to facilitate access to the best places to receive sporting events in proportion to the nature of the activity, climate, numbers involved and the ability to make updates in the least time.

\section{Conclusions and recommendations:}

\section{Conclusions: First: The first axis}

- There are no sporting facilities in the governorate that can be used for sports tourism purposes, and the current sporting facilities in the governorate are not suitable for sports tourism.

- Sports facilities in Luxor Governorate do not have specialized workers who are aware of the concepts of sport tourism.

\section{Second: The second axis:}

- There is a trend by the Ministry of Youth and Sports to establish sports facilities capable of hosting major sporting events in Luxor Governorate.

- There is a budget allocated by the government to support sport tourism.

- The Ministry of Tourism does not commit tourist companies to providing brochures to motivate tourists to practice sports activities in them. There are no legislations related to sports tourism.

\section{Third: The third axis:}

- The importance of establishing a sports stadium in Luxor is to eliminate unemployment, provide job opportunities, revive national income and maximize profitability.

- The public benefiting from the construction of the sports stadium in Luxor includes foreign and Arab tourists who support sports, athletes participating in events or sports championship, media professionals, coaches and administrators, and public who are interested in sports.

- The country benefits from sports tourism through financial and economic returns resulting from hosting events or championship.

\section{Fourth: The fourth axis}

- The Ministry of Youth and Sports has a budget for the construction of a sports stadium in the Governorate.

- The human power needed to operate the sports stadium are the general manager, the executive director, an accountant, the administrative director, the public relations specialist, the marketer, the marketing specialist, the lighting technician, the sports supervisor, the electrical technician, the electronics technician, the maintenance technician for the tools and devices, the agricultural workers, storekeeper, financial manager, support services.

- The necessary organizational structure for the proposed sports stadium in Luxor Governorate is represented by the Facilities and Construction Department, Public Relation, Ceremonies and Celebrations official, Agricultural Engineering Department, 
Electrical Department, Technical Workshops Department, Financial Affairs Department, Administrative Affairs Department, and Stadiums and Activities Department.

Second: Presenting the conclusions of the feasibility study to establish a sports stadium to stimulate sport tourism in Luxor

First: A technical feasibility study to establish a sports stadium to stimulate sport tourism in Luxor

- Choosing the suitable site for establishing the sports stadium in Luxor.

- Design estimates for the sports stadium (auditoriums that accommodate about $(80,000)$ spectators divided into three classes, first, second and third, auditorium for those with special needs (300) seats, a compartement equipped with a balcony for VIPs (250), the presidential area (1), a hall for VIPs ( 1), stadium lighting towers (4) dressing rooms for players (4), referees rooms (2), dope detecting rooms (1), radio and sound control room (2), fully equipped cafeterias (2), guesthouse (1), administrative offices (6), meeting room (2), media center equipped with Internet (1), electronic gates (20), parking places (3), physiotherapy center (1), therapeutic unit (1), storage (2), toilets for the public (10), electricity control room (2).

\section{Estimated basic needs for machinery, equipment and furniture:}

Electronic scoreboard (2) on both sides of the stadium with the latest technology, large TV screen $32 \mathrm{~m} \times 15 \mathrm{~m}$ (2), communication facilities near the main compartement (1), internal and external communication devices, computers (5), printers (4), internal and external speakers (30), surveillance cameras (30), generators (6), (80000) seats for the public, seats for people with special needs (300), seats for players and journalists (120), seats for VIP visitors (250), Seats for players and administrators (120) divided for two teams, offices (50), administrative cabinets (50), lockers for players (120), tables (30), conference platform (1), furniture (2), air conditioning (40), air conditioning and televisions installations $(40+27)$, TV screen (15).

\section{Estimated human needs for sports stadium:}

General Manager (1), Financial Director (1), Accounts Officer (2), Administrative Director (1), Public Relations official (1), Marketer (1), Marketing Specialist (2), Lighting Technician (2), Sport Supervisor (14), Support Services (20), Carpentry Technician (1), Plumber Technician (1), Electrical Technician (2), Electronics Technician (2), Instrumentation and Hardware Officer (2), Agricultural Engineer (1), Workers Agriculturalists (2), storekeeper (2).

Second: The financial feasibility study to establish a sports stadium to stimulate sports tourism in Luxor.

- Exchange items for the establishment of a sports stadium in Luxor Governorate (engineering design for the stadium, infrastructure, attachments attached to the stadium, furniture and equipment, tools and devices).

- Operating exchange items for the sports stadium in Luxor (one-year salaries of employees (60 employees), administrative expenses, maintenance at $10 \%$ of equipment costs, depreciation of $10 \%$ of equipment costs).

- Marketing exchange items for the sports stadium in Luxor (design of a stadium 
website, an advertising campaign for the stadium and its activities, an electronic sports magazine for the stadium and tourism).

- Estimating the return from establishing a sports stadium in Luxor Governorate (selling tickets, matches and competitions, special seats, holding conferences, sponsoring companies for the championship, renting the stadium for various sporting events, tourists following sports events).

Third: Marketing feasibility study for establishing a sports stadium to stimulate sport tourism in Luxor.

- Development of a recreational plan for the sports stadium by the Ministry of (Youth and Sports, Tourism).

- A website with information about the stadium, events and tourist places.

- Attracting sponsors to activities organized in the stadium to gain highest income.

- Connecting the website with the different sports sites.

- Issuing an electronic and paper sports magazine for the stadium and its activities.

Fourth: A social feasibility study to establish a sports stadium to stimulate sports tourism in Luxor.

- Provides job opportunities for the citizens of the country in general and the governorate in particular.

- Increased national income from the operation of the stadium.

- Achieve a social benefit for the governerate and put it on the sports tourism map.

- Intercultural exchange between nations due to sports meetings.

- Increased awareness of the importance of sport in Upper Egypt.

Fifth: A legal feasibility study to establish a sports stadium to stimulate sports tourism in Luxor

- Determine the legal entity of the sports stadium.

- Identify the competent authorities to supervise the project, the Ministry of Youth and Sports.

- Determine the responsibility for building the stadium through tenders.

- The obligation to pay the taxes due and all government dues.

- Make all licenses for the sports stadium project.

Recommendations: In light of the research results, it is recommended:

- Inclusion of a Department of Faculties of Physical Education, Tourism and Hotels to prepare specialized human cadres in the field of sports tourism.

- To establish a joint plan in coordination between the ministries of tourism, youth and sports to achieve the goals of sport tourism in Egypt.

- Create a website and link it with other sports sites to provide all information about sporting events.

- Foreign sports teams should be encouraged to come to Luxor to set up their training 
camps, which will contribute to the advancement of sports tourism.

- Providing specialized human power and resources to develop sport tourism in the Arab Republic of Egypt.

- Providing a full sports map for tourist attractions in different languages.

- The necessity of issuing a clause in the sporting entities law that serves to stimulate sport tourism and tourist attraction in the Arab Republic of Egypt.

- The necessity of putting a feasibility study to establish a sports stadium for improving sports tourism in Luxor, to be implemented.

\section{References:}

1 Abdel-Motaleb AbdelHameed Mohamed (2000)

2 Ahmed Abdel-Samie Allam (2008)

3 Ahmed Mahmoud Mokabla (2007)

4 Ahmed Nabil Kamel ElShiekh (2004)

5 Ashraf Samir Al-Meydane (2005)

6 Battoluc,M.Orrcen.D,Andrij asevic.M(2006)

7 Bassma Ibrahim AbdelBaseer(2015)

8 Buckley,M. Ferd (2010)

9 Central Agency for Public Mobilization and Statistics (2019)

10 Emama Samir Mohamed (2000)

11 Farid Hassaneen Farid

12 Freyer, W(,2001)

13 Gasim Mohamed AbdelHakim (2003)

14 Hammad Karam El-Kabee (2012)

15 Hammad Yeno Omar ELSayed (2006)
Economic feasibility studies for investment decision-making, University House, Alexandria.

Technical and economic feasibility study and project evaluation, University House, Alexandria.

Tourism Industry, First Edition, Kenooz Al-Marefaa, Library of the Faculty of Tourism and Hotels, Helwan University.

The role of sports tourism in developing resources in sports federations in the A.R.E., unpublished master's thesis, Faculty of Physical Education for Boys, Zagazig University.

Sports tourism in Egypt, Dar Al-Wafa for Printing and Publishing, Alexandria.

Economic basis of the development of sports tourism exemplified by a model of entrepreneurship Acta- Turistica,18(1): 52-75.

The Economic Feasibility Study of the Egyptian Football Association, The Scientific Journal of Physical Education and Sports Science, No. 75, Part Two, 565-558, September, Cairo.

TourismContribution in Economic crisis, Travel and tourism. Annual Bulletin of Cultural Statistics, Ministry of Tourism, Arab Republic of Egypt.

Evaluation of sports tourism marketing methods in Egypt, unpublished Master Thesis, Faculty of Tourism and Hotels, Alexandria University.

Tourism in Egypt, Dar El-Shorouk, Cairo.

Sport and Tourismus, Megamarket In Der WissenSchaftlchen Disk ussion In troslen, G.

Tourism industry in Emirates "Dubai", Publications of the Department of Culture and Information, Sharjah Government, United Arab Emirates.

"Evaluating the possibilities of sports tourism in the United Arab Emirates", unpublished Ph.D. thesis, College of Physical Education for Boys, University of Alexandria.

The role of sport tourism in developing the tourist attraction in the Arab Republic of Egypt, unpublished Master Thesis, Faculty of Physical Education for Boys, Mansoura University. 
16 $(2011)$

17 Hassan Abeed Fahme (2017)

18 Haytham Bahha El-Din Hassan (2018)

19 Heather J. Gibson: (2007)

20 Ibrahim Mahmoud AbdelMaksoud, Hassan Ahmed ElShafei (2004)

21 Khalifa Taleb Bahbhani (2001)

22 Khalifa Taleb Bahbhani, Gawaad Khalaf Hashim (2001)

23 Kurtman J Zauhar (2005)

24 Mohamed Hassaan Mohamed (2015)

25 Mohamed Mahomud Dehieba (2007)

26 Mohamed Moneer Higab (2002)

27 Mona Abdel-Aziz Essaa (2008)

28 Nadia Lotfy Abdel-Fatah Moawad (2008)

29 Nadia Lotfy Abdel-Fatah Moawad (2012)

\section{Preuss ,Messing(2002)}

\section{Ruaridh Arrow (2008)}

32 Saber Hassan Omar (2006)

33 Salah Osman Yousef (2013)

34 Salem Khalaf Fahd (2017)

35 Sally Said Abdu (2016)
The role of sport tourism in facing the economic crisis in the Arab Republic of Egypt "Unpublished Ph.D. thesis, Faculty of Physical Education, Mansoura University.

Technology and sports facilities, Eshaa Center for Publishing and Distribution, Amman.

Databases and their importance, Dar Jarir for Publishing and Distribution, Amman

Sport tourism, published by: rout ledge, $24^{\text {th }}$ December.

Scientific Encyclopedia of Sports Management (Relationships -

Administrative Development - Marketing and Finance in the Sports

Field - Tourism is a Source for Sports Financing), Dar Al-Wafaa for Printing and Publishing, Alexandria.

Evaluating the potential of sports tourism in Kuwait, No. 13, Part 1, November, Journal of the Faculty of Physical Education for Boys, Assiut University.

Evaluating the potential of sports tourism in Kuwait, No. 13, Part 1, Assiut Journal of Physical Education Science and Arts, Egypt.

\section{$J$ the emerging profession sports tourism management journal of sport tourism ,10(1)3-14.}

Luxor Governorate Book.

Tourism Geography, 1st Edition, Arab Community Library, Amman.

Tourist information, Dar Al-Fajr for publication and distribution, Cairo.

Evaluating the potential of sports tourism in Kuwait, unpublished Master Thesis, College of Physical Education for Boys, Alexandria University.

Organizing the Olympic Games and their Economic Impact on the Host Countries, Unpublished Master Thesis, College of Physical Education for Girls, University of Alexandria.

Feasibility studies for the investment in Al-Olimbi Egyptian Club, unpublished Ph.D. thesis, Department of Sports Management, Faculty of Physical Education for Girls, Alexandria University.

,M,Ausland Tusland Tourise beiden olympischen Spielen in Sydney in Dreyer,A,(Hrsg) tourismus und sport wesbaden. Satellite TV Feasibility Study,Media Support Solutions.

Evaluation of water activities in tourism projects in the Arab Republic of Egypt, unpublished Master Thesis, Faculty of Physical Education for Boys in Al Haram, Helwan University.

Sports Institutions Administration, Dar Al-Fikr Al-Arabi, Cairo.

Feasibility study to invest in the facilities of Al-Zawra Club in Iraq, unpublished Ph.D. thesis, College of Physical Education for Girls, Alexandria University.

A future vision for the advancement of sports tourism in the light of contemporary challenges, the seventh international scientific conference (human development and contemporary sports issues), Faculty of Physical Education for Girls, Helwan University, Egypt. 
36 Walaa Mohamed Ibrahim (2011)

\section{Weaver:D \&} Lawton:L(2009)

38 Youssef Attia El-Thebeity (2010)

39 http://aqu.edu.iq/el/mod/resourcelview.php?id=3529.

40 https://www.luxor.gov.eg 2019/2/23
A study of the reality of recreational tourism in Alexandria Governorate, unpublished Master Thesis, Department of Recreation, Faculty of Physical Education for Girls, Alexandria University.

Tourism and economic development; tourism Mangment U.S census Bureau: October.

Sports Finance, King Fahd National Library for Publishing, Kingdom of Saudi Arabia. 